Florida International University FIU Digital Commons

\title{
Authentic Servant-Leadership Exemplified by Early Childhood Educator David Lawrence Jr.: A Case Study
}

Blanca Correa-Cespedes

Florida International University, bcorr005@fiu.edu

DOI: $10.25148 /$ etd.FIDC000271

Follow this and additional works at: https://digitalcommons.fiu.edu/etd

Part of the Business Administration, Management, and Operations Commons, Educational Leadership Commons, Human Resources Management Commons, Leadership Studies Commons, Nonprofit Administration and Management Commons, Organizational Behavior and Theory Commons, Organization Development Commons, Other Educational Administration and Supervision Commons, Pre-Elementary, Early Childhood, Kindergarten Teacher Education Commons, and the Urban Education Commons

\section{Recommended Citation}

Correa-Cespedes, Blanca, "Authentic Servant-Leadership Exemplified by Early Childhood Educator David Lawrence Jr.: A Case Study" (2016). FIU Electronic Theses and Dissertations. 2453.

https://digitalcommons.fiu.edu/etd/2453 


\section{FLORIDA INTERNATIONAL UNIVERSITY}

Miami, Florida

\section{AUTHENTIC SERVANT-LEADERSHIP EXEMPLIFIED \\ BY EARLY CHILDHOOD EDUCATOR DAVID LAWRENCE JR.:}

A CASE STUDY

A dissertation submitted in partial fulfillment of

the requirements for the degree of

DOCTOR OF EDUCATION

in

EDUCATIONAL ADMINISTRATION AND SUPERVISION

by

Blanca Correa-Cespedes

2016 
To: Dean Michael R. Heithaus

College of Arts, Sciences and Education

This dissertation, written by Blanca Correa-Cespedes, and entitled Authentic ServantLeadership Exemplified by Early Childhood Educator David Lawrence Jr.: A Case Study, having been approved in respect to style and intellectual content, is referred to you for judgment.

We have read this dissertation and recommend that it be approved.

$\begin{array}{r}\hline \text { Delia C. Garcia } \\ \hline \text { Thomas G. Reio } \\ \hline \text { Linda Spears-Bunton } \\ \hline \text { Peter J. Cistone, Major Professor }\end{array}$

Date of Defense: March 31, 2016

The dissertation of Blanca Correa-Cespedes is approved.

Dean Michael R. Heithaus
College of Arts, Sciences and Education

College of Arts, Sciences and Education

Andrés G. Gil

Vice President for Research and Economic Development and Dean of the University Graduate School

Florida International University, 2016 
(C) Copyright 2016 by Blanca Correa-Cespedes.

All rights reserved. 


\section{DEDICATION}

I dedicate this dissertation to my husband, Joe Cespedes, and my children Nick, Mia, Enzo and Ian. I hope that completing this doctoral marathon will be a model for their journey. May we always choose to DREAM BIG and work harder than expected. I love you to the moon and back forever. 


\section{ACKNOWLEDGMENTS}

I want to express my deepest gratitude to my major professor, Dr. Peter Cistone, and the dissertation committee. Their support with the process to complete this project was beyond encouraging. I would also like to acknowledge Dr. Isadore Newman for his expertise; and Dr. Linda Bliss whose ongoing guidance made this qualitative dissertation possible.

I also want to honor my father in heaven who inspired me to pursue a greater mission than myself. Papi was unable to complete his doctoral studies at La Universidad de la Habana since he became a political exile in the United States, but this degree is to honor his legacy. A special thanks to my mother who was my first teacher and an exemplar of selflessness. Her unconditional love and support has taught me priceless lessons to this day. My brothers and sisters, biological and spiritual have reminded me to press on. You know your name. Thank you to Lea Coto who sent me the MDCPS Weekly Briefing for the CLAVE scholarship and insisted that I pursue being called Doc. Also, to the DLK8 Family who have sharpened my character and intellect, especially Miss Lemus who cheered me on and on from IRB to final draft.

Finally, I would like to acknowledge and thank each participant who agreed to share their time to be interviewed. I especially want to thank David Lawrence Jr. who humbly allowed me to expose his strengths and weaknesses all for the love of learning and helping me. This study would not have been possible without each of them. 
ABSTRACT OF THE DISSERTATION

\title{
AUTHENTIC SERVANT-LEADERSHIP EXEMPLIFIED BY EARLY CHILDHOOD EDUCATOR DAVID LAWRENCE JR: A CASE STUDY
}

\author{
by \\ Blanca Correa-Cespedes \\ Florida International University, 2016 \\ Miami, Florida \\ Professor Peter J. Cistone, Major Professor
}

Advocacy and leadership style are essential concepts in education. This qualitative case study was undertaken to demonstrate how the servant-leadership framework could be a useful framework for adoption by educational leaders and child advocates. The study contributed to understanding the value of exemplary servant-leadership and advocacy in public education as demonstrated by David Lawrence Jr., a model of servant-leadership traits. The researcher addressed questions regarding servant-leadership and explained how servant-leadership could influence public educational policy.

The research questions addressed advocacy, leadership style and impact on early childhood education in Florida as evident by the model's words and actions. Sixteen interviews were conducted with individuals from four interest groups in Florida: business leaders, political leaders, local South Florida leaders and educational leaders. In addition, coded data were gathered by observing Lawrence in both public and private events as well as interviewing the identified case participants in multiple settings. The findings verified the servant-leadership framework and identified five emerging themes modeled by Lawrence that have contributed to his influence on public educational policy. 
A paradigm shift from authoritarian leadership to an authentic servant-leadership style that advocates for young children and promotes the importance of early childhood educational policy is a topic that required further investigation. The dichotomy examined throughout this research focused on servant-leadership and advocacy that is instrumental to make a difference in education as an educational leader navigates through political agendas. Lawrence, exemplar servant-leader, leads a Children's Movement in Florida that includes an ongoing bipartisan movement that has changed early childhood education in Florida. The findings of this investigation validate that servant-leadership framework could influence the transformation of public education. 


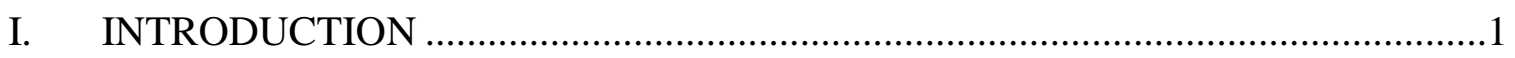

Background of the Study ……………................................................................

Purpose of the Study .........................................................................................6

Research Questions ........................................................................................

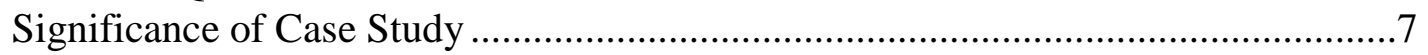

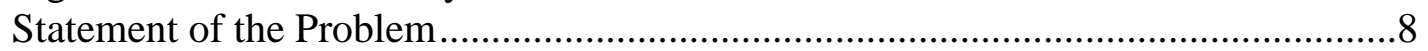

Theoretical Framework ....................................................................................

Definition of Terms .......................................................................................14

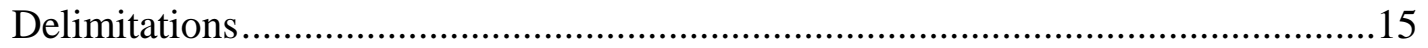

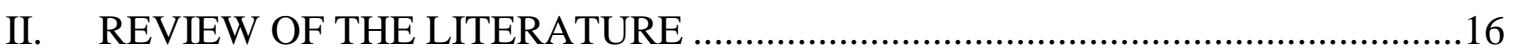

Emergence of a New Early Childhood Movement ..................................................17

Advocates...................................................................................................20

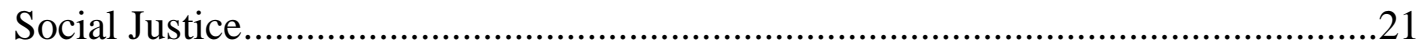

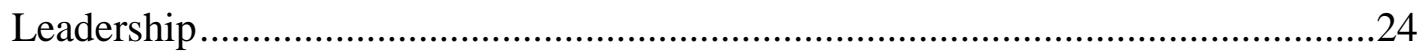

Authentic Servant-Leadership ............................................................................2

Educational Policy ........................................................................................28

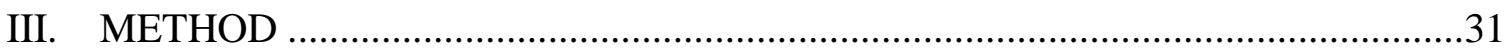

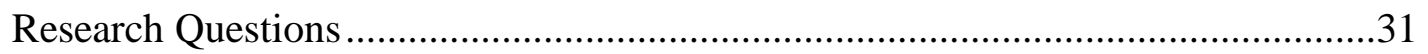

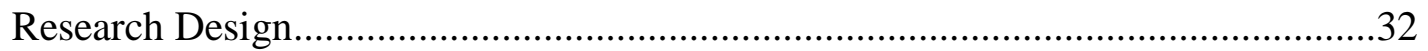

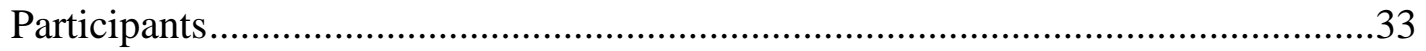

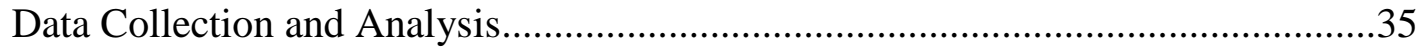

Interviewing Questions ..........................................................................................36

Trustworthy Strategies and Dependability...............................................................37

Role of the Researcher .........................................................................................38

Assumptions...............................................................................................

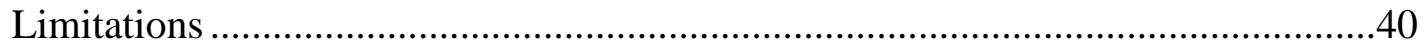

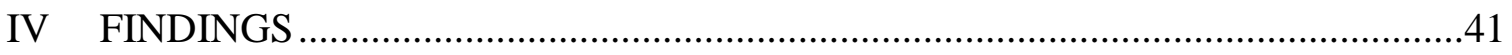

David Lawrence Jr. .........................................................................................42

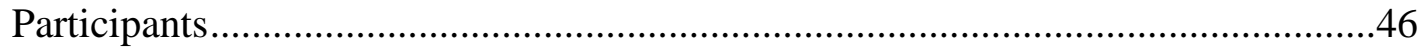

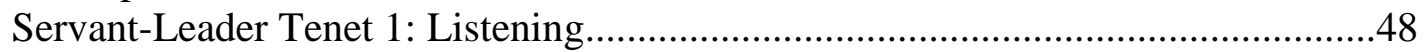

Servant-Leader Tenet 2: Empathy …………………............................................50

Servant-Leader Tenet 3: Healing ..............................................................................52

Servant-Leader Tenet 4: Awareness ………………….........................................55

Servant-Leader Tenet 5: Persuasion …………………..........................................57

Servant-Leader Tenet 6: Conceptualization............................................................62

Servant-Leader Tenet 7: Foresight.........................................................................65

Servant-Leader Tenet 8: Stewardship .......................................................................72

Servant-Leader Tenet 9: Commitment to the growth of others ..................................75

Servant-Leader Tenet 10: Building Community.......................................................79 


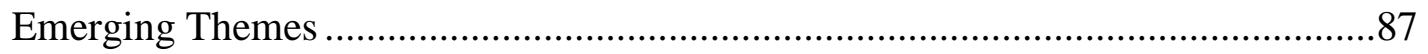

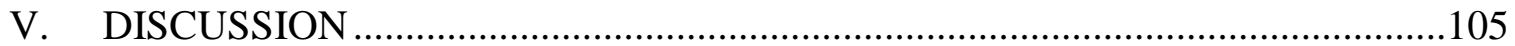

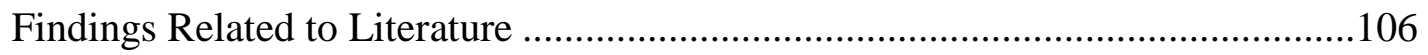

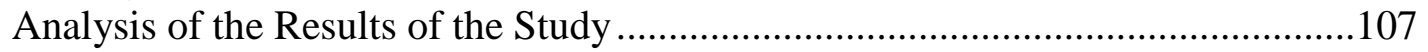

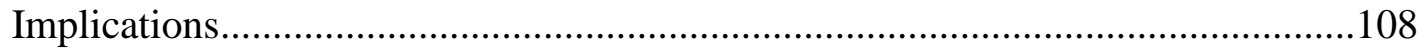

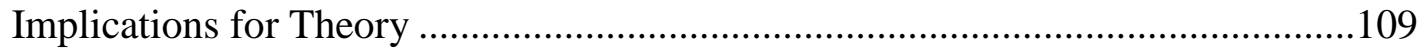

Implications for Future Research.............................................................110

Implications for Practice and Conclusions .....................................................111

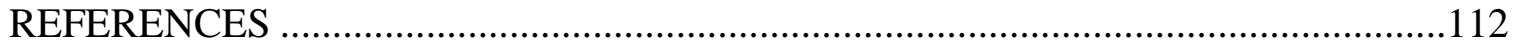

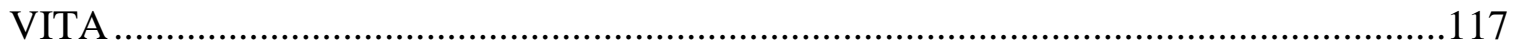




\section{CHAPTER I \\ INTRODUCTION}

A leader speaks to the people we want to be, the community we want to be, and the country we want to be and should be. (Lawrence, 2014a)

Advocacy and leadership style are essential concepts in education and particularly in early childhood education. The youngest members of society, children from ages birth to eight, depend on adults for their future development. Young individuals lack the understanding and maturity to perceive subtle forms of oppression from educational leaders and political agendas. Moreover, children lack the power to advocate for themselves. These same children are dependent on the decisions and actions of educational leaders. The leader's motive as well as the leader's intention for future generations is revealed through educational policies and procedures. Freire's writings

give value to the voice of the poor, of the dispossessed, of the oppressed, of those with no voice (Torres, 2014). As Freire has stated (2000), a leader's philosophical views and political agenda can be revealed through the subtle oppression of those whose lives are at stake. He addressed the oppressed, like vulnerable children, as stakeholders in a community who lack freedom to reach their full potential, but are not aware of the conditions that stifle them as oppressed individuals.

The dire current situation of education in the United States cannot be ignored. In spite of the amount of money spent on public education many children, especially the poor and children of color, continue to fail both academically and socially. Current behaviors that contribute to unintentional injuries and violence among children are reported by the Centers for Disease Control and Prevention, 2011 Youth Risk Behavior 
Surveillance System. Children suffer from bullying and other violent crimes daily. According to the National Center for Education Statistics, the amount of educational funding has more than doubled in the past 15 years, yet discussions regarding the lack of reading, math and science proficiency continue. Although through the years additional funds have been poured into public education, the disparity in educational outcomes, specifically among black and Hispanic males, continues. In 2015, the National Assessment of Educational Progress (NAEP) reported that more than one third of fourth and eighth graders performed at or above a proficient achievement level in reading, while the goal is to have "no child left behind.” In 2015, the percentages of selected student groups performing at or above proficiency in Grade 4 ranged from $18 \%$ for black students to 57\% for Asian students. At Grade 8, the percentages at or above proficiency ranged from $16 \%$ for black students to 54\% for Asian students. NAEP findings reveal that students also need to improve in math and science. In addition to the scores that show a lack of proficiency, many boys are not making adequate progress, particularly in urban areas. The risks to future generations is shown in the downward test scores and increasing incarceration trends.

Educational leaders may be failing our children. Social problems among children are linked to criminal behaviors among young adults and economic failures in society. Both social and academic outcomes are evidence that the existing sophisticated leadership and ongoing educational rhetoric is not solving the ongoing problem in education today. Educational leaders can no longer play the game of politics without reflecting on why students are failing (Lochner \& Moretti, 2004). A paradigm shift is needed to develop effective educational leaders. Trendy reforms in public education that 
favor academic success promote short-term solutions instead of creating a foundation that, with time, will solve issues related to low student achievement (Kirp, 2013). Trendy reforms that include science, technology, engineering and mathematics (STEM) or other curriculum trends fail to focus on educational leaders as a factor that could improve the existing social and academic challenges in our schools today. The dichotomy examined in this research is servant-leadership and child advocacy. A servant-leader's perspective may oppose trendy reforms that drive educational political agendas and distract others from addressing the existing needs of all children within existing public education organizations. Educational servant-leaders can and should identify the current needs of all children as a primary goal of leadership. Advocacy and authentic servant-leadership are therefore essential concepts in the field of educational leadership, especially when addressing educational political agendas.

A role model of authentic servant-leadership demonstrates traits and behaviors that can influence educational policy. Authentic leadership signifies genuineness and conveys to the follower that the leader is the real thing (Bishop, 2013). This qualitative study examined the leadership qualities of an authentic servant-leader. That is, a genuine leader that has a service leadership lens. The research presented data describing the work of an exemplar named David Lawrence Jr. (“Lawrence”), a child advocate who has influenced and continues to influence policymaking specific to early childhood education in Florida and throughout the United States. A servant-leader strives to navigate the political arena to meet the needs of the youngest members of society. Throughout the United States, courage with humility is needed to persuade a community to examine priorities for a more compassionate society. An authentic servant-leader in early 
childhood advocates for all children and pursues the necessary venues to move an agenda that is in the best interest of all children. In order to produce notable achievements both academically and socially among all student demographics, leadership style needs to be addressed.

In everything, advocacy for children acknowledges the value of every child and all children irrespective of race. A servant-leader is a particular type of leader who challenges society's view of leadership practices. A servant-leader in early childhood education is on a mission to bring awareness and change to the current state of affairs regarding the youngest members of society. A servant-leader may reiterate that the greatest return on investment for a society comes from investing in the youngest members of society during the years of a child's early stages of development. Like a farmer who takes care of the earliest stages of the harvest, an educational servant-leader invests time, talent, finance and influence in the early educational programs in order to have the most profit and return on investment in the later school years. The overall wellbeing of a child begins at the earliest stages of life (Moore \& Oberklaid, 2010).

\section{Background of the Study}

As a doctoral candidate, I have engaged in ongoing reflection and identified different leadership practices among educators in public education. Additionally, in the Pedagogy of the Oppressed, Freire (2000) suggested there is a need to further understand the process of teaching and learning as well as the oppression of the individuals dehumanized in the process. Therefore, I "chose to write about leadership: the relational process and practices through which people come together to make things happen. No 
matter what form, relationships are at the heart of leadership and its capacity to make things happen" (Whitney, Trosten-Bloom, \& Rader, 2010, p. 4).

After reflecting specifically on the past 10 years of interaction with Lawrence and reflecting on the role of educational leaders to serve all children, I recognized Lawrence's influence as an authentic-servant leader. Therefore, I chose to conduct a formal investigation of Lawrence's leadership style and advocacy. I have been afforded opportunities to engage in ongoing dialogues with Lawrence through the years, and I have observed him in multiple event settings throughout South Florida. Lawrence is consistent about his platform and mission to change the world for every child and all children, exemplifying authentic servant-leadership traits as he continues to advocate for them. My passion for leadership is aligned with the tenets of a servant-leader, and therefore I chose this leadership style for further research.

As a Title I public school administrator in an urban area in South Florida serving students that attend a school named after Lawrence, I found the topic of research to be historically appropriate. My background consists of more than 27 years in the field of public education and a deep-rooted passion for all children. My experiences have provoked in me a deep desire in researching qualities of a highly effective leader. The complexity of authentic servant-leadership was investigated and analyzed as modeled by an exemplar servant-leader. In a timely manner, Lawrence, has established an early childhood movement and created the Early Childhood Initiative Foundation in Florida. Servant-leadership can influence educational policy with a different approach to the current leadership styles practiced by educational leaders. This is why I chose to further investigate authentic servant-leadership. Lawrence’s leadership traits could make a 
difference in public education to efficiently and with urgency move political agendas specific to the best interest of all children. A healthy family life, a safe community, medical care, quality education and healthy eating are things to consider that are in the best interest of all children.

A review of literature about advocacy, leadership practices, and early educational policy revealed a gap of information that suggested the need for further research. A gap between servant-leadership style and positive outcomes in school organizations was identified. Research questions were formulated. The following sections of this qualitative case study present a description of the problem and purpose of the research, the research questions, the theoretical framework, the rationale, and significance of this case study.

\section{Purpose of the Study}

This qualitative case study about servant-leadership informs professional practices and provides evidence regarding how leadership style may influence policymaking pertinent to education (Baxter \& Jack, 2008). This study provides insight for learning about servant-leadership and child advocacy in educational politics. Lawrence is a model of servant-leadership highlighted in this case study.

This case study focused on a paradigm shift in the existing leadership styles to servant-leadership in order to improve public education. A shift from an egocentric leadership style to an authentic servant-leadership style that promotes child advocacy would positively influence public education. Yin (2003) addresses how specific theoretical propositions about feasibility of a study can address future implications. In this case study the implication would be future educational policies through leadership style. The case study provides insight into leadership style and advocacy as it relates to 
educational policy. Lawrence's leadership style provides an example of this phenomenon;

therefore, he is the subject of this case study. The research describes Lawrence's ongoing bipartisan children's movement that has changed early childhood education in Florida and challenges all members of society.

\section{Research Questions}

The major research question of this study is: How has David Lawrence Jr.'s specific characteristics of servant-leadership influenced others in the political arena to implement selected improvements in the field of early childhood education?

Additional questions are:

1) What is it about the failing of public education that has led to considering a servant-leadership framework for educational leaders and child advocates?

2) How can the servant-leadership framework be used to prepare educational leaders for improving public education?

\section{Significance of Case Study}

Qualitative researchers study subjects in their natural settings, attempting to make sense of, or interpret phenomena in terms of the meanings people bring to them (Denzin \& Lincoln, 2011). A paradigm shift to servant-leadership is the focus of this case study as modeled by Lawrence. The research included observations in different community involvement settings as well as private dialogues with one exemplar leader. The researcher also conducted one-on-one interviews with 16 participants and reviewed articles, speeches, websites specific to the topic, and ongoing field notes to have rich data to describe servant-leadership and child advocacy as a possible solution to address the problem in public education. 
A paradigm shift to an authentic servant-leadership style is necessary in education to address the ongoing concerns in public education. The servant-leader was a servant first, rather than a leader. This means that the servant-leader had the responsibility to be the seeker of the needs, the wants, and the wishes of others who would be served (Greenleaf, 1970). Servant-leadership may facilitate the objective of meeting the educational goal of improving student outcomes. This study focused on servantleadership and advocacy to ultimately improve schooling for all children.

\section{Statement of the Problem}

This qualitative study describes a leadership style that contributes to positive educational policies and that advocates for all children. The findings of this case study pertained to specific theoretical propositions about feasibility (Yin, 2003) to move future educational policies and resolve the ongoing educational concern of meeting the needs of all children. The qualitative researcher of this study emphasized the process from a philosophical perspective, through an interpretive lens, and on to the procedures involved in studying social or human problems (Creswell, 2013, p.43) specific to educational leadership. For years, public education has attempted to address students' achievement or the lack thereof. Advocates and educational leaders continue to address low student performance, yet the obvious problem of leadership continues to be ignored. Every child needs an advocate. This means that although every child is supposedly a valued individual investment for society from the earliest stages of life, other agendas continue to take priority in making educational political decisions. Educational leaders serving public schools must adopt a new mindset of service to positively influence the next generation. 
Today's educational reform decisions cast the die for generations to come.

Advocates and leaders alike use the same political rhetoric to make decisions. The choice of words seems promising for the cause at hand, yet the actions do not follow the promises. There are advocates who speak up on behalf of children, and there are leaders influencing educational political agendas. Advocates and leaders can be two separate groups. The rhetoric points to the need for social justice and reform through the platform of public education, yet authentic servant-leaders choosing to advocate for the best interest of all children are an anomaly. The logical solution for educational reform is overlooked: address the needs of all children as early as possible through quality schooling (Lochner \& Moretti, 2004).

Lawrence focuses on the needs of the youngest children in society to produce the most positive long-term outcomes. He believes that the return on investment for society is greatest when the investment starts with the youngest members (Lawrence, 2014a). The solution suggested by Lawrence is high quality early childhood intervention. The ongoing conversation among leaders addresses the educational foundation of every child in order to achieve better results for society. Lawrence is a model for authentic servantleadership and child advocacy as he takes action as the founder of a movement that addresses the interrelated developmental needs of a child's intellectual, emotional, social, physical, artistic, creative, and spiritual potential (Miller, 1997).

\section{Theoretical Framework}

Robert K. Greenleaf coined the phrase "the servant as leader" which is based upon a biblical concept. Servant-leadership is a philosophy and deliberate practice that builds the lives of others to ultimately create a more just and caring world. The servant-leader's 
mission is to pursue making the world a better place. A servant-leader type is the extreme opposite of any traditional leadership style where the leader's priority is to secure power or acquire material possessions. Servant-leaders use their power to make the weak strong. The servant-leader's qualities aim to contribute to the well-being and success of those being served (Greenleaf, 1977).

An authentic servant-leader desires to serve first, and through a mindful consciousness chooses to lead others to develop their potential to produce positive outcomes for society. The focus on cultivating human qualities, such as intellectual skills (Dweck, 2006), is a growth mindset in servant-leaders. Authentic servant-leadership qualities and an intentional growth mindset provide the lens for this study. Research attempts to identify the differences in leadership styles and the influence that these differences make in society.

In Reflections on Leadership, Greenleaf and Larry R. Spears (1996) identify the 10 core qualities of a servant-leader. The qualities of a servant-leader can be applied to any field. Servant-leadership would benefit the field of education by developing leaders with a different leadership style than the current self-centered leadership exhibited by educational leaders (Greenleaf, 1970). For this study each trait has been related to the topic of education.

\section{Listening}

Leaders have traditionally been valued for their communication and decisionmaking skills. Although these are also important skills for the servant-leader, they need to be reinforced by a deep commitment to listening intently to others. The servant-leader seeks to identify the will of a group and helps to clarify that will. He or she listens 
receptively to what is spoken. Listening also encompasses the leader getting in touch with one's own inner voice. Listening, coupled with periods of reflection, is essential to the growth and well-being of the servant-leader.

\section{Empathy}

The servant-leader strives to understand and empathize with others. People need to be accepted and recognized for their special and unique traits. One assumes the good intentions of others and does not reject them as people, even when one may be forced to reject certain behaviors or performance. The most successful servant-leaders are those who have become skilled empathetic listeners.

\section{Healing}

The healing of relationships is a powerful force for transformation and integration. One of the great strengths of servant-leadership is the potential for healing one's self and one's relationship to others. Many people have broken spirits and have suffered from a variety of emotional hurts. Although this is a part of being human, servant-leaders recognize that they have an opportunity to help make whole those with whom they come in contact.

\section{Awareness}

General awareness, and especially self-awareness, strengthens the servant-leader. Awareness helps one in understanding issues involving ethics, power, and values. It helps the leader be able to view most situations from a more integrated, holistic position.

\section{Persuasion}

Another characteristic of servant-leaders is reliance on persuasion, rather than on their positional authority, in making decisions within an organization. The servant-leader 
seeks to convince others, rather than coerce compliance. This particular element offers one of the clearest distinctions between the traditional authoritarian leadership model and that of servant-leadership. The servant-leader is effective at building consensus within groups. This emphasis on persuasion over coercion finds its roots in the beliefs of the Religious Society of Friends (Quakers).

\section{Conceptualization}

Servant-leaders seek to nurture their abilities to dream great dreams. The ability to look at a problem or an organization from a conceptualizing perspective means that one must think beyond day-to-day realities. For many leaders, this is a characteristic that requires discipline and practice. The traditional leader is consumed by the need to achieve short-term operational goals. The leader who wishes also to be a servant-leader must stretch their thinking to encompass broader-based conceptual thinking. Servant-leaders are called to seek a delicate balance between conceptual thinking and a day-to-day operational approach (Greenleaf, 1970). In education, the gifted servant-leader has the ability to have a vision for every child and to pursue making opportunities realities, even for the youngest members of society.

\section{Foresight}

Closely related to conceptualization, the ability to foresee the likely outcome of a situation is hard to define but easier to identify. One knows foresight when one experiences it. Foresight is a characteristic that enables the servant-leader to understand the lessons from the past, the realities of the present, and the likely consequences of a decision for the future. It is also deeply rooted within the intuitive mind. Foresight 
remains a largely unexplored area in leadership studies but is one characteristic shared by servant-leaders (Greenleaf, 1970).

\section{Stewardship}

Servant-leaders believe medical and educational opportunities must be addressed for the well-being of all children for the greater good of society. Servant-leadership, like stewardship, assumes first and foremost a commitment to serving the needs of others. It also emphasizes the use of openness and persuasion rather than control.

\section{Commitment to the growth of people}

Servant-leaders believe that people have an intrinsic value beyond their tangible contributions specific to a situation. As such, the servant-leader is deeply committed to the growth of every individual. This is a key concept with quality early childhood education. The servant-leader recognizes the tremendous responsibility to do everything in his or her power to nurture the growth of every child from the earliest stages of development. A servant-leader demonstrates a commitment to the future of the youngest members of society, whether rich or poor (Greenleaf, 1970).

\section{Building community}

The servant-leader senses that much has been lost in recent human history regarding the care of others (Greenleaf, 1970). Technological advances result in a shift from local communities to large institutions as the primary shapers of human lives. This phenomenon creates a false sense of leaders caring for the oppressed and seeking selfish gain. Leaders must be intentional about creating smaller authentic learning communities where people help one another improve society. This awareness motivates and inspires 
the servant-leader to seek to identify means for building community starting with the youngest stakeholders.

\section{Definition of Terms}

Advocacy is defined as the process an individual engages in to influence political decisions and policymaking.

Appropriate refers to a condition that is positive, right, and fair for all individuals involved in a situation, regardless of age.

Authentic leadership is the field of study and method of practice in terms of values, ethics, and self-will. This brand of leadership exhibits both intrinsic and external values. The description of the leadership style connotes genuineness and conveys to the follower that the leader is the real thing (Bishop, 2013, p. 1).

Early childhood education practice is described as the issues of interest to early childhood development and theory from birth through eight years of age for every child as defined by Early Childhood Research Quarterly (2014), affiliated with the National Association for the Education of Young Children.

Game-changer is a contemporary classification for a modern-day servant-leader. It puts serving the greater needs of others as the primary goal of leadership. This leadership style understands the political arena of distribution of advantages and disadvantages. A game-changer understands that the public square is where politics are played out.

Leadership is multifaceted and may be described in many ways. A leader has interaction with other people who may or may not follow the leader. Relationships that 
evolve between leaders and followers are crucial in achieving and sustaining leadership goals (Ebbeck \& Waniganayake, 2005).

Politics is defined as a contest of the distribution of advantages and disadvantages. Education has become a highly political arena because it is in the public square where politics are played out.

Policy is the selected course government chooses to follow.

Servant-Leadership is a concept originated by Robert K. Greenleaf in 1964 as "the servant as leader." It puts serving the greater needs of others as the primary goal of leadership. Servant-leaders choose to serve others regardless of the age.

Social is defined as interaction with others. In this study, social development refers to the ability a child has to choose appropriate behaviors to interact with peers and other individuals. Appropriate behaviors are based on the individual's age and needs essential for the child's healthy development.

\section{Delimitations}

The first delimitation identified in this study is that only one exemplary leader is examined for this research. The second delimitation is that the "servant as leader" definition is based on Greenleaf's theoretical framework. The choice of using Greenleaf's framework identifies a theoretical framework of 10 specific traits specific to servant-leaders, although the literature identifies other leadership styles and traits. The chapter that follows, presents a review of the literature in leadership, social justice and advocacy. 


\section{CHAPTER II}

\section{REVIEW OF THE LITERATURE}

The concepts of advocacy, leadership, and early childhood educational policy are presented in this chapter through a review of literature relevant to the study. This chapter also addresses the aspects of politics and policy linked to early childhood education of poor children (McLoyd, 1998). In addition, the researcher examined qualities of a leader that influence early childhood education initiatives to address economically and educationally disadvantaged children (McLoyd, 1998). Educational leaders influence all children's educational foundation. Finally, this literature review explains the origins of servant-leadership that date back to ancient times.

Greek and Roman philosophers established schools of thought of self-awareness

and internalized moral perspective as well as the concept of transparency and authenticity among leaders. In the Christian tradition, it is written in the Gospel of Mark 10:43-45 and Matthew 20:26, whoever wants to be a great leader must be willing to serve others, as the Son of God who came to serve and sacrifice his life for the atonement of all people (Norton, 1996). Ancient scriptures have defined authenticity and servant-leadership; however in postmodern civilization the simplicity of these terms and practice have been adulterated by materialism. Materialism, electronics, and man-made distractions desensitize people to the pleasures of nature and sustainable living (Orr, 2004, p. 143). The materialistic environment then influences behaviors that can either instill in humanity the desire to make the world a better place or to continue in behaviors that harm others and the environment. 
Reflection and self-awareness allows for a continuum of progress. One of the most influential Western philosophers during the late 1700s was Immanuel Kant. Kant's devotion to duty and doing what is expected is part of both his transcendental idealism and his empirical realism. Kant's school of thought was named deontological ethics. Kant challenged morality to be defined as the action always necessary according to the dictates of reason. In Kant's view, moral worth is not the outcome that is achieved by the action, but the motive that is behind the action (Johnson, 2012). According to Kant, it is right to do what is moral based on a set of universal principles discovered by reason, and there is no exception to the rule. In truth, Kant's theory of devotion to duty is idealistic. Kant's fixed principles or truths enable a constant philosophical perspective. Kant's rigorous puritanical upbringing influenced him with moral views and values that are not common practice today. His idealism, if applied to education and in relation to all children, could transform public education. A child advocate would be devoted to the duty to seek the best for all children, and an authentic servant-leader would pursue the law that allows the devotion to duty to be achieved.

\section{Emergence of a New Early Childhood Movement}

The history and goals of public schools involve controversies surrounding politics, social issues, and economics. Education has become a highly political arena (Cistone, 2013). Public schools were intended to serve the public, hence the relationship to politics and public policy. Yet, stakeholders in public education address the goals of local school boards and the agendas that have the greatest influence among the leaders in the field (Marshall, 2005). The various mechanisms that allow reform to be adopted through public education vary throughout different educational communities. 
Early childhood education and the educational practice of birth through eight years of age was not a focus in the beginnings of public education. Children's social, emotional, cognitive, behavioral, and linguistic development and the efficacy of early intervention (Bryant, 1992) were not part of the early public school mission. This historical approach, elitist in nature, created division among students from the beginning of public education in the United States.

During the 1600s, the traditional family consisted of a mother, a father, and children. Hence, early childhood concerns were addressed at home by the mother rather than in a school setting. In the late 1790s in the United States, another political decision was made when the call for free public education exclusively for poor children was established. Prior to then, the "wealthy" were expected to pay for their children's education and provide financial support to educate the laboring force. Political, social, and economic goals historically created a distinction between private and public education (Marshall, 2005). Horace Mann was influential in the Massachusetts Reform, where children who refused to attend public schools were enrolled in "reform schools" that combined the education and the juvenile justice systems. This set an elitist tone from the beginning of public education for even the youngest members of society.

Around the same time, in Europe, Friedrich Froebel established the first kindergarten in Germany in 1837. His early childhood program was intended to be a garden for children, where children would grow and develop in healthy freedom. Froebel is credited for being the founder of the philosophy of the true nature of play, which organically developed into the ethics of work. Children learn to work through early development and play. Froebel's educational philosophy was influenced by Johann 
Heinrich Pestalozzi, an educator who welcomed the poor and orphans into the Frankfurt Model School. This revolutionary practice that Pestalozzi implemented in the 1800s inspired Froebel. Froebel was motherless before the age of one and yearned to provide children a loving, supportive environment in which to thrive and grow (Pioneers, 2000).

Froebel's philosophy inspired Elizabeth Palmer Peabody. Born in Massachusetts in 1804, she passionately pursued the cause of early childhood education and opened the nation's first formal kindergarten in Boston in 1860. The early years of the educational system were based on the early colonists' agenda. A child's future and opportunities were clearly established for every child based on his or her social class, gender and race. Either a child was born into a wealthy family and offered the opportunity to develop through age-appropriate play at home with an educated family, or the child was born into poverty or slavery and the cycle of an unfortunate social status continued. The opportunity for a strong educational foundation has been linked to the elite since the earliest stages of American education (Marshall, 2005).

The roots of early childhood education began with Froebel. Additional contributions came from John Dewey who presented the Pedagogical Creed and other educational theories and social reforms in the 1930s. He also discussed democracy and education for children. Maria Montessori, Lev Vygotsky, and Jean Piaget were all contributors to the sensory approach and playing to learn for young children during the same time (Early Childhood Today, 2000). Quality early childhood education served the purpose of setting an educational ready foundation for children.

Politics, social issues, and economics are a controversial trifecta of discussion in education when agendas are moving the goal of educating students. Politics and social 
issues endorsing trendy reforms exist in public schools. In spite of the history of public education and reform, public schooling continues to be linked to ulterior agendas. The oxymoron of public education exists in the subtle mechanisms that contribute to ideological control (Chomsky, 2011, p. 31). In theory, education in the United States is intended to provide knowledge and to develop each student to his or her full potential. By law, all school-aged children are entitled to a free and appropriate public education. It is precisely in the population of urban school that children find the highest concentration of poverty and racially oppressed groups (Berlowitz \& Long, 2011, p. 185), and yet the rhetorical question of how to best address the needs of all children continues among educational leaders.

Advocates and leaders alike use the agenda of education to advance social justice or ulterior motives. Lawrence is the founder of the early childhood movement that continues to engage thoughts of social change for all children, in spite of the opposing realities provided throughout 150 years of lack of historical evidence in early childhood educational policy. Lawrence is pursuing an answer to the need for improvement in public education, and the solution starts with high quality early childhood education for all children.

\section{Advocates}

A parent is defined as any family member, including a blended or extended family member or other adult, such as a grandparent, stepparent, or someone standing in loco parentis, who plays an important role in the child's life or contributes to the learning of the child and his or her improvement in school. Parental involvement in schooling is a means to link the positive effects of student achievement and lifelong learning (NCLB 
Parental Involvement Guide, 2002). But not every child has an involved parent, and therefore the need for educational leaders to advocate and focus on the early stages and needs of children must be a priority for public policy (Lawrence, 2014).

Many parents face obstacles in their attempts to become involved in schools. A few of the obstacles include lack of parent education and parenting skills, language barriers, cultural differences, parent illiteracy, and family problems (Plevyak, 2003). Advocates and leaders in the community can establish agendas that move policies that increase student academic achievement through early childhood intervention opportunities. As child advocates, leaders must reflect on their own theoretical framework and embrace a leadership style that will advance early childhood education policies to benefit the youngest members of society. The relationship between advocacy, leadership, and early childhood can well address the need for social justice in education.

The two main professional antecedents of the field of early childhood that clearly link to the future of society are education and the human service component. "High quality" early education strives to achieve the development and welfare of children "to become or not to become; that is the question" (Ebbeck \& Waniganayake, 2005, p.10). Therefore, advocates and leaders in public education continue to address the relationship between educational fundamentals and the outcomes that impact culture and society.

\section{Social Justice}

Mildred Norman represents advocacy and authentic leadership for social justice and illustrates authentic practice of a theory becoming reality in a leader's life. Peace Pilgrim (Janis n.d.) is a documentary that depicts Norman living her life as a peace 
pilgrim in lieu of simply talking about the practice. The Peace Pilgrim's story provokes ongoing dialogue regarding authentic leadership to support social justice. In October 2014, Lawrence also walked a pilgrimage for the cause of all children. Like Norman, Lawrence reflects on the experience of walking the rhetoric for the social justice of all children. Lawrence chooses to walk the talk, as evident in his documented journey across the top of Northern Spain on social media (Fernandez, 2014). That pilgrimage ultimately led to support for The Children's Movement of Florida.

Freire (2000), in Pedagogy of the Oppressed, argued that oppression is a real issue that does not disappear without a dialogue for social change and action. As leaders choose to ignore political decisions that are not beneficial for all children, authentic servant-leaders choose to address the obvious in public education and to advocate on behalf of the children. Advocacy and authentic leaders address social justice to promote meeting the needs of the youngest members of society. All children have the right to quality education that will serve as the foundation for a positive future.

In a democratic society, the collaboration of all stakeholders to provide all children the same opportunities is a fair argument for advocates and educational leaders. Leaders in early childhood education make a difference in children's lives and learnings. As advocates reflect on their theoretical framework, educational policies and program effectiveness are established (Smith, 2007). Educational leaders have an opportunity to reflect on professional practice and leadership actions that support the rhetoric of making all children a priority.

The nature of the reality or knowledge of early childhood education varies according to the theoretical and empirical perspectives. Freire (2000) addresses the 
marginalized groups and the oppressed in education. Freire describes an oppressive system that retains control and takes the role of the oppressor, while the student is expected to be passive. Educational policy and research explore the cause of social justice in relationship to public education. Cultural relativism or any relativism that denies absolute truth compromises the basic human rights of all people. Aristotle defined absolute truth as "things that cannot be other than what they are," and the right of every child to receive quality education regardless of social class is right and fair.

Theoretically, transformation and social justice identify historical factors that relate to oppression that exists in public education. The pedagogy of the oppressed as a perspective to further investigate the reformation of public education (Freire, 2000) presents the need for a paradigm shift in leadership style that addresses public education and human rights of the less fortunate, specifically the youngest members of society. Freire presents the reality that the fortunate and influential have dominated the oppressed by maintaining control over the life of the less knowledgeable. The youngest members of society are least developed both intellectually and physically, therefore making the possibility to marginalize them a successful strategy for oppression.

Education and political agendas can address social justice. This can become a controversial approach to policymaking because values and beliefs vary in a democratic society. Educational objectives can be defined in a variety of ways depending on who is involved and where the influence of the schooling rests (Connelly, He, \& Phillion, 2008). As an early childhood program is implemented, various elements determine the level of manipulation of the stakeholders. Manipulation attempts to anesthetize people so they do 
not think and inoculate individuals with the bourgeois appetite for personal success (Freire, 2000).

Education is not a neutral arena. Educational policies can be used to reinforce structures of domination. When a leader's motive is to build every child to meet their full potential, education can be used to promote social transformation. People learn faster and are happier when educational content is relevant to their lives and when the method is based on authentic dialogue and respect. Therefore, the importance of recognizing both the political dimension of education and the pedagogical dimensions of politics enables authentic educational reform (Torres, 2014).

\section{Leadership}

Leadership philosophies have varied throughout history since the time of Socrates and Aristotle (300 B.C.E.). The great Greek philosophers engaged in intellectual dialogues about great ideas. These ideas attempted to understand people, relationships and social structures that move individual and collective agendas in a civilized community today. Socratic discussions have served as a foundation to further address conversations regarding the basic tenets of how society effectively operates in an organizational structure. The philosophical ideas have provided a foundation for the ancient authentic servant-leader framework to change the culture of existing communities.

Mahatma Gandhi, Martin Luther King Jr., Mother Teresa, and Nelson Mandela are examples of servant-leaders who have lived out a pursuit or a cause greater than self. Sociology, psychology, and scientific theories attempt to detail the science that establishes the success of leadership types that can influence an organization with a 
selfless mission. Each historical era has provided organizational theories the opportunity to find evidence to explain how politics and power combine theoretical frameworks to effectively advance each cause at a specific time in history. Authentic servant-leaders are not described by others as having an inflated sense of their own importance nor a deep need for admiration from others. Contrary to displaying a need for self-validation by seeking prominence, authentic servant-leaders model exceptional compassion and empathy for others with an urgency to serve and leave the world a better place (Greenleaf, 1970).

Different leaders believe different theories. There is a clear link between the belief system of a leader and that leader's style of leadership. During the industrial era, organizations focused on accomplishing one task and mastery of one goal. The division of labor was specific and proportional to the production. It was a time of dexterity in every worker as outcome performance was vital in the workplace. Leadership style was structured to produce the expected results. In the beginning of established organizational leadership, organizations were committed to saving time and resources. The inventions of machinery clearly supported the goal of production and replaced the work of many people. These times impacted educational leadership because the same philosophy carried over to public education. The long-term goal of developing the individual rather than focusing on production was not a priority among leaders (Bolman \& Deal, 1991).

. During the early 1900s and throughout the growth of the Industrial Revolution, the scientific management and rational systems of organizations developed. Systems continued to be simply goal oriented. The division of labor was clear to establish necessary growth. Organizations began to divide by specialization and expertise, a 
division which clearly created a formal setting within a system. The public education system adopted the same philosophy. The hierarchy and discipline during this era was part of social growth. The scientific management leadership style and the relation to an ineffective work mentality influenced educational leadership.

Research-based and scientific approaches began establishing the rational approach of effective work patterns (Bolman \& Deal, 1991). Standardization became a norm as goals were met within a system. This classical mindset is the foundation of every organization, rather than the new mindset of shaping society through a bedrock of highquality early childhood education. This is also a humanistic approach to create a positive culture for society (Deal \& Peterson, 2009).

Mary Antonaros defined leadership style in gendered terms that include traditionally "agentic" styles for men and "communal" styles for women (Antonaros, 2010). Communal refers to a group of people interacting and sharing a common goal. Agentic has been defined as a social cognition theory perspective that views men as selforganizing, self-reflecting, and proactive. Men have been described as leaders who may have the capacity of making choices without the influence of a community. On the other hand, women have been described as communal leaders because they relate to others in the organization to lead effectively. There is a balance created with these two perspectives work together for a greater cause.

The term "transformational leadership" was introduced by James MacGregor Burns in 1978. According to Burns, leaders and followers help each other advance to a higher level of morale and motivation. An early childhood education advocate with a transformational leadership style inspires followers to work toward the common goal of 
early childhood education, but a servant-leader goes beyond transforming to serving the mission at hand. Lawrence has publicly announced his intention to work for the common good of all children through his commitment to The Children's Movement of Florida.

\section{Authentic Servant-Leadership}

Authentic leadership is one style of leadership. The style is composed of moral behavior that is based on a system of values that aligns with a particular perception of reality. If the topic at hand is early childhood education, then an authentic leader focuses on the interest of all children regarding early childhood. This means the return on investment made in the life of all children would result in the children becoming educated members of society, and an authentic leader would have a clear vision to the mission.

The development of authentic leadership evolves through relationships with others who share a common vision and mission. To be an authentic leader, one must be ethically accountable and true to oneself as related to the collective good of others (Bishop, 2013). It is crucial for effective leaders to know who they are and where they have been. People can identify authenticity and appreciate leaders who are true to their beliefs and do not back down (Novak, 2012).

The servant as leader term was coined by Robert K. Greenleaf in his 1970 publication titled The Servant as Leader. Greenleaf describes the servant-leader as one who makes a conscious choice to aspire and is driven beyond selfish motives. This type of leader goes beyond the need to possess power to drive others and is not motivated by the desire to acquire material possessions (Spears, 1996). The servant-leader, according to Greenleaf, makes other people's highest priority needs the goal to accomplish. The servant-leader addresses the needs of how people grow to be healthier, wiser, freer, and 
more autonomous, and therefore will grow to become leaders who will choose to make a positive influence in the world. The servant-leader theoretical framework is the lens used for this case study. The authentic servant-leader is true to the selfless mission of serving others.

\section{Educational Policy}

President Barack Obama said in this State of the Union Address on February 12, 2013, that "In states that make it a priority to educate our youngest children...studies show students grow up more likely to read and do math at grade level, graduate high school, hold a job, form more stable families of their own. We know this works. So let's do what works and make sure none of our children start the race of life already behind." Obama's call to action requires advocacy and leadership for early childhood education to be a priority in policymaking and implementation.

The educational policymaking process is an adversarial process, characterized by the competing and conflicting viewpoints and interests rather than an impartial, disinterested, or "objective" search for "correct" solutions for policy problems. In theory, the creating policy process follows clear stages that include (a) the policy on the agenda, (b) the formulation of the policy, (c) the adoption of the policy, (d) the implementation of the policy, and finally (e) the evaluation of the policy (Marshall, 2005 p. 50). These clearly defined stages do not highlight the controversial element of policymaking.

Educational policymaking does not stand alone from other societal issues that become valid agendas that create adversity for the educational policymaking process. Major public policy questions are decided both in the legislature and in the courts, in spite of the goodwill of educational leaders in local arenas. The reality that educational 
leaders have to juggle politics creates a partial policymaking process that enables hidden participants to be involved in the policy stream (Kingdon, 2011).

Advocacy and leadership style play a key role in navigating through public policy to advance early childhood education. The motives that define the advocate and leader drive the educational and political agenda that is supported by the individual. As educational policymaking occurs, special interests rather than an objective search for policy solutions are the ongoing rhetoric of educational reform. The intertwined policies that create the framework for education make the process complicated and with no simple solution (Marshall, 2005, p. 184). Layers of state and local government create an educational policymaking process that is not simple to comprehend. The federal government establishes rules and regulations. The state has additional policies to follow. At the local level, challenges that do not support the implementation of policy as intended by politicians are a reality. This vicious cycle of agendas, alternatives and public policies characterize the conflicting viewpoints for policy in education. Yet, highly effective leadership finds a way to move the necessary agenda to address the needs of the youngest members of society through ongoing efforts.

The Foundation for Child Development commissions case studies that offer firsthand accounts of groundbreaking policy development and practice. The Foundation for Child Development seeks to document efforts in education and advocacy organizations to create a well-aligned and high-quality early childhood education for all children in the United States (Hampton, 2004). In the November 2002 election, Floridians put on the ballot by petitions signed by 722,000 voters, a constitutional amendment that made available state-paid, voluntary, universal prekindergarten 
education (UPK) for all 4-year-olds, which was to start in 2005. No other state's voters had ever mandated UPK by themselves (Hampton, 2004, p.2).

Although it may be argued that Freire's philosophy of education speaks to a political audience, the reoccurring theme in research and theoretical literature makes a connection between practical educational systems and policies throughout the world (Irwin, 2012, p.18). Education is a major platform to promote political agendas. Yet a gap exists in research regarding early childhood education, advocacy, and leadership in policymaking. Prior to the 1960s, early childhood education was not a priority because the traditional family nucleus was still a part of the American culture for some. The setting for most children consisted of a parent at home meeting their educational and other needs. Traditionally, mothers would nurture their young children as part of the social norms to follow in the United States, while fathers modeled work ethics for the young children. In 1964, the Head Start program was funded by the Economic Opportunities Act to meet the social injustice dilemmas of young children in the United States. Lawrence often refers to his own personal experiences as a young child, when his mother and father routinely instilled the importance of the core values mentioned above. These family values have made him a leading advocate in Florida for early childhood education and young children. 


\section{CHAPTER III}

\section{METHOD}

A paradigm shift to an authentic servant-leadership style is necessary in education. This qualitative case study of servant-leadership as exemplified by a renowned early childhood advocate and educational leader informs professional practices and provides evidence regarding how leadership style can influence policymaking pertinent to education (Baxter \& Jack, 2008). David Lawrence Jr. is an exemplar of servantleadership in the field of educational politics and policy. This study provides insight for learning about the influences of child advocacy and leadership style in educational politics. The empirical evidence of this case study was specific to field oriented work identified through patterns and meanings directly interpreted from information provided by the identified informants and the researcher’s data collection (Stake, 1995).

\section{Research Questions}

The major research question of this study is:

How has David Lawrence Jr.’s specific characteristics of servant-leadership influenced others in the political arena to implement selected improvements in the field of early childhood education?

Additional questions include:

1) How did the failings of public education led to considering a servant-leadership framework for educational leaders and child advocates?

2) Can servant-leadership framework be used to prepare educational leaders for improving public education? 


\section{Research Design}

This chapter describes the methodology of this case study and the variety of data that were gathered by the researcher. Multiple methods of data collection enabled the writer to address the research questions of this qualitative case study. The evidence came from fieldwork notes, archival articles, verbal reports, and observations that collectively contributed to the study (Yin, 1981). Rather than relying on a single data source, this qualitative case study presents Lawrence as an example of a servant-leader and child advocate through 16 interviews with people who had work experience with Lawrence, observations of Lawrence conducted over three months of interaction, speeches, published articles, and additional documents.

According to Yin (2003), a case study design should be considered when (a) the focus of the study is to answer "how" and "why" questions, (b) the researcher cannot manipulate the behavior of those involved in the study, (c) the researcher wants to cover contextual conditions because the researcher believes they are relevant to the phenomenon under study, or (d) the boundaries are not clear between the phenomenon and context. Lawrence is an exemplar identified in this research to better understand child advocacy and authentic servant-leadership that influences educational policy.

Both Stake (1995) and Yin (2003) state that they base their approach to a case study on a constructivist paradigm. Constructivists argue that truth is relative and depend on the researcher's perspective. Constructivism is built upon the premise of a social construction of reality (Searle, 1995). One of the advantages of this approach is the close collaboration between the researcher and the participants involved, enabling participants to tell their stories (Crabtree \& Miller, 1999). Through these stories, the participants are 
able to describe their views of reality, and this then enables the researcher to better understand the participants' actions (Lather, 1992; Robottom \& Hart, 1993).

The researcher in this case study used a deductive approach. Servant-leadership is explained by using David Lawrence Jr. as a highlighted educational leader. Empirical evidence was gathered and analyzed. The research of servant-leadership involved careful observation of the objective reality that exists in this story (Creswell, 2008) and therefore rejects a relativist's perspective. The objective truth in this study resulted from the analysis of the rich and robust data gathered that deducts a framework that supports the traits of a servant-leader.

The analysis of the data gathered provided a better understanding of an advocate and servant-leader who has a mission to meet the needs of young children and influence early childhood educational politics. This case study is delivered from the perspective of an objective truth regarding advocacy and authentic servant-leadership (Creswell, 2008). This case study attempts to explain an objective reality of the common issues facing public education, and how a newcomer to educational leadership has influenced educational policy. Lawrence has made a lasting contribution to the field of education and has made a commitment to pursue his mission that all children in the United States have the right to a quality early childhood opportunity.

\section{Participants}

The initial list of possible participants included 25 individuals identified as key local influential members of society who have worked with Lawrence either before or after his years as a publisher. The researcher understood that not every possible participant would be available for the research study. Therefore, the population sampling 
used was reduced to 16 specific individuals. The first 10 individuals were contacted via email. Each individual contacted expressed a willingness to help with the research study. Additional participants were added to provide rich data from each category developed from the compiled group.

The interviewees were individuals from four interest groups in Florida; business leaders, political leaders, local South Florida leaders, and educational leaders. The business leaders included Jorge Perez (Related Group), Mike Fernandez (MBF Healthcare Partners), and Carol Jenkins Barnett (Publix Super Markets). The political leaders interviewed included Senator Bob Graham, former mayor of Miami-Dade County Alex Penelas, state director Vance Aloupis from The Children's Movement of Florida, and Florida Governor Rick Scott. The local South Florida leaders interviewed were Alberto Ibarguen from the Knight Foundation, Bishop Victor T. Curry from New Birth Baptist Church, and physician Judith Schaechter from the University of Miami, Pediatrics-Adolescent Medicine. The educational leaders interviewed included physician Pedro Jose "Joe" Greer Jr. from Florida International University’s Medical School; Joe Natoli, current chief financial officer at the University of Miami; Evelio Torres, current chief executive officer of the Early Learning Coalition, and professor Raquel Diaz from the University of Florida.

The average interview was 45 minutes. The semi-structured format of each interview allowed for further clarification for the answers provided. Each participant willingly provided elaborate answers and demonstrated a positive attitude about contributing to the study. 


\section{Data Collection and Analysis}

The researcher used NVivo software to code the data and find examples of similar concepts throughout the data. The data were sorted on paper first to focus on leadership framework concepts as well as the advocacy traits Lawrence displays. The written notes, reviews of recordings, and transcriptions were later uploaded to the software.

The decision to use the QSR International NVivo10 software to organize and analyze the data collection process allowed for clear patterns and meanings to be identified. All interview audio recordings were professionally transcribed and each participant was offered the opportunity to verify accuracy of transcription. All participants were satisfied with the process and none requested revisions. In addition, a peer reviewer provided the researcher with ongoing feedback regarding the documentation. Throughout the writing process two colleagues who are also doctorate students at other universities, reviewed the working draft of this dissertation. Ongoing feedback was provided by each peer reviewer.

All gathered data was uploaded to NVivo. Following the transcribing and the audio reviews, coding and queries were done using NVivo Software. Text frequencies were listed. The initial coding, which broke down the interview data into concepts to then further analyze the information acquired, allowed the researcher to identify themes in the study as described in the initial coding cycle (Saldana, 2013). Codes were based on Greenleaf's 10 servant-leadership characteristics. Coding attributes of Lawrence exemplar servant-leadership style were clearly identified. Although additional leadership characteristics were identified, the focus on patterns and themes was narrowed down to Lawrence's servant-leadership traits and the top five reoccurring themes. The initial 
mass data collected were sifted through a servant-leadership framework and the qualities of a child advocate used to influence educational policy were further analyzed.

The findings of this case study were based on qualitative methodology and the data reported ongoing themes of servant-leadership modeled by Lawrence. The case study provided a unique perspective into the understanding of how educational politics and policy are influenced by a specific leadership style. Each participant was interviewed for approximately 45 minutes. Two of the 16 participants (Barnett and Scott) were not available in person; therefore, email interviews were agreed upon by the researcher and the participant. Both Barnett and Scott provided detailed answers to the interview questions. The other participants who agreed to be in the study scheduled one-on-one interviews with the researcher. The time and location were agreed upon by each participant and the researcher. All interviews were recorded.

\section{Interviewing Questions}

The participants were each asked the following questions in order:

1. Please tell me in what context you know David Lawrence Jr.

2. How would you describe David Lawrence Jr.?

3. What can you please tell me about David Lawrence Jr.'s leadership?

4. What do you think motivates David Lawrence Jr. regarding early childhood?

5. What can you tell me about David Lawrence Jr. and his interest in young children?

6. What can you please tell me about David Lawrence Jr.'s influence on policymaking, specifically his involvement in early childhood education in Florida? 
Each participant was asked the questions in the same order. As the participants elaborated on their experiences with Lawrence, additional follow-up and probing questions were asked of some of the participants in order to gather additional information regarding Lawrence’s leadership and influence. The probing questions were specific to each interview as were asked in the context of the information that was shared by the participant.

\section{Trustworthy Strategies and Dependability}

The interview records, photographs of the researcher with each participant, transcriptions, and handwritten notes were kept private and protected to the fullest extent provided by the law by the use of locked software and files in the researcher's home office. All guidelines relating to materials set by Florida International University Graduate School were followed. Additionally, approval from the Institutional Review Board was obtained to conduct this case study. A signed adult consent for participation was provided by each participant.

To provide trustworthiness and dependability to the study, steps were followed to secure the process of preparing, conducting, and writing the case study. Throughout each interview, field notes were taken and key concepts highlighted as the participants repeated ideas during the interview. Finally, contextual occurrences of words and concepts were linked to the interview recordings and the transcriptions. Peer review editing by other doctoral students also allowed for clarification and transparency of themes developed. Peer reviewers were doctoral students who are also colleagues of the researcher. The documentation steps, themes identified, and interviewees' verification of transcriptions strengthen the trustworthiness and dependability of the study's findings. 
Each recording was transcribed by a third party. After each face-to-face interview was transcribed the transcription along with a photograph was emailed to the participant for review. No revisions or editing was requested of the information emailed to the participants. Each participant provided valuable self-evidence of his or her relationship with David Lawrence Jr. Concepts and themes clearly reoccurred throughout the interviews and further explained the focus of this study.

\section{Role of the Researcher}

My interest in this case study is directly related to the characteristics of David Lawrence Jr. as an exemplar authentic servant-leader who has influenced educational politics and policy. I met Lawrence when I was appointed to be one of the site administrators for a new school that was being built and would be named after him David Lawrence Jr. K-8 Center in North Miami. During the school's inaugural year, David Lawrence Jr. visited the school numerous times. Each time I had an encounter with Lawrence, I observed leadership qualities unique to him and not commonly seen among other educational leaders in public education. When Lawrence visited the school, he always asked two questions. The first question was: "How are you doing?" Then as someone who is genuinely interested in the answer to the question, he would pause to await for a personal response rather than a generic "Fine, and you." The next question Lawrence would ask would be intended to provoke deep thinking: "What was the last book you read?" followed by an inquiry about the reading selection.

After each experience and interaction with Lawrence, I would reflect about my role as an educational leader. Regardless of the context or setting of the visit, each time the outcome could be described in the same way regarding Lawrence's actions and words. 
Lawrence listens empathically to everyone he encounters. His behavior consistently displays a commitment to the growth of others. He engages in conversation with others to build awareness of each individual's unique story. His obvious platform and mission throughout multiple event settings in South Florida were consistent in leadership style. He did not change rhetoric or actions regarding his passion for early childhood education and the youngest members of society.

After 27 years in public education, I came to believe that a formal investigation into leadership in educational political arenas and particularly as to why certain leaders can advance a political agenda while others cannot, could add insight to the current literature. Meeting and getting to know David Lawrence Jr. inspired me to pursue a formal investigation of authentic servant-leadership and advocacy for all children, especially for children in public schools. Each participant's feedback was consistent with my experience regarding Lawrence's being a role model for servant-leadership and advocacy for all children.

\section{Assumptions}

The assumptions made in this case study were:

- David Lawrence Jr.'s servant-leadership style is a plausible model for influencing educational policy and creating a movement to benefit all children everywhere.

- Educational leaders influence the potential success of students and are directly related to the implementation of policy at a school site.

- All educational leaders are child advocates who want to improve the quality of life for all children and in turn improve society as a whole. 
- All educational leaders want to serve the needs of "all" children and believe every child is valuable member of society.

- Student performance and outcomes improve as educational leaders make social justice a priority in educational policymaking.

\section{Limitations}

One obvious limitation of this case study is that each participant has a contextual relationship with Lawrence. The close collaboration between the researcher and the participants can also be a limitation. Another limitation is whether participants have been honest about the information provided rather than pushing their own agendas. 


\section{CHAPTER IV}

\section{FINDINGS}

The researcher conducted three interviews with Lawrence and 16 interviews with individuals who are familiar with him. Each individual has either worked with Lawrence in the publishing industry or has collaborated in the early childhood movement with David Lawrence Jr. in Florida, and therefore is familiar with Lawrence's advocacy and leadership qualities. Each participant has played a role in moving the early childhood agenda in South Florida. The recorded interviews averaged 45 minutes in duration. The variety of data sources ensured that the topic was not explored through one single lens but rather through a variety of lenses, which allowed for multiple facets of the phenomenon to be revealed and understood (Baxter \& Jack, 2008, p. 544).

Methodology can refer to the use of data analysis and the conceptual framework that defines the research (Mills, Eurepos, \& Wiebe, 2010). The servant-leadership framework was chosen for this study. The method of direct observation used in this study enabled the researcher to describe Lawrence's story and his specific leadership style that has influenced early childhood educational politics and policy in Florida. The interviews conducted were coded by patterns and themes.

The findings of this qualitative study presented in this chapter could help educational leaders better understand the behaviors and traits of an authentic servantleader. Servant-leadership was explained by using Lawrence as an exemplar educational leader. The major research question of this study was answered in this chapter: 
How has David Lawrence Jr.'s specific characteristics of servant-leadership influenced others in the political arena to implement selected improvements in the field of early childhood education?

The data collected presents the servant-leadership framework, traits and behaviors of Lawrence. In addition, themes with supporting evidence that emerged from the interviews and data are included. These themes provide additional evidence of the need for a shift in leadership style if educational reform is to occur.

\section{David Lawrence Jr.}

David Lawrence Jr. had spent 35 years on his first career as a journalist, a reporter, and an editor and publisher of seven newspapers. In 1999 he retired from his position as publisher of The Miami Herald and began to work full time on early childhood policy. His priority is and has always been the earliest years of every child. Lawrence was particularly energized and excited by the concept that by investing in highquality early education governments can save money that would have been spent for academic remediation, law enforcement, or incarceration. He started his advocacy mission in Florida and has dedicated the last 15 years of his life to a career as an educational leader promoting equity and investment in the early years of education for all children through The Children's Movement, an organization which has significantly influenced children's educational and social policy in Florida. Most notably under Lawrence's leadership as the chairman of The Children's Trust in 2008, The Trust in an economic downturn persuaded 2.4 million residents of Florida's largest and politically diverse county to agree to a tax to support children (Merzer, 2008). Lawrence's leadership spearheaded the campaign for the reauthorization of the original 2002 ballot 
initiative. Florida voters chose to tax themselves in perpetuity on behalf of early childhood programs with a tax that produced around \$100 million each year. These South Florida taxpayers and others were inspired by Lawrence to join his bipartisan organization "The Children's Movement" (Merzer, 2008).

Money and materialism do not drive Lawrence's leadership (Alex Penelas, personal communication, August 8, 2015). Following a successful career as a journalist, Lawrence chose to pursue a mission greater than himself. Lawrence models servantleadership as the Gospel of Luke 18:16 states "that the greatest servant will take care of the little children" (Norton, 1996) and he has become a model educational leader who is making ongoing contributions for all children in the United States. Lawrence as an exemplar servant-leader has influenced and continues to influences educational policy and politics.

Lawrence's story as a model of authentic servant-leader helps better explain and describe a set of interpretive, material, and objective practices that give value to young children in society. These practices have the potential to transform the world into a series of representations, including field notes, interviews, speeches, and letters that describe the importance of the case study (Creswell, 2013, p.45).

An authentic servant-leadership framework can be traced back to biblical times; Robert K. Greenleaf coined the biblically grounded concept label in 1970s by identifying the servant as a leader (Greenleaf, 1977) and suggested that servant-leadership as a deliberate practice can build the lives of others to ultimately create a more just and caring world. This theoretical lens was used to explain a type of leadership style modeled by Lawrence. A servant-leader has the mission to pursue making the world a better place. 
Lawrence as the exemplar leader of this research study is on mission to impact early childhood education and advocate on behalf of the youngest members of society.

There are 10 core qualities displayed by a servant-leader according to Greenleaf and Spears (1996) in Reflections on Leadership. They are:

- Listening

- Empathy

- Healing

- Awareness

- Persuasion

- Conceptualization

- Foresight

- Stewardship

- Commitment to the growth of people

- Building community

Servant-leaders are intentional about creating positive communities where people help one another to improve society and overcome social injustices. This awareness motivates a servant-leader to seek to identify tangible ways of building community. According to the findings, Lawrence displays these qualities and he is an example of a servant-leader who chooses to make his cause the focus of improving the world by starting with the youngest stakeholders in society. During an Oklahoma City Early Childhood Summit, Lawrence explained that:

money, yes, is important, but it is not the first focus. Rather I start with the matter of priorities- how can it be in this, the richest country in the world, that so many 
children of Florida and Oklahoma live in the full federal definition of poverty? (Lawrence, 2015)

One purpose of this case study was to facilitate an understanding of how and why a paradigm shift to an authentic servant-leadership style is desirable in public education. The study focused on advocacy and authentic servant-leadership as exemplified by Lawrence. He states "Our best leaders are servant leaders. In the words of the first nonEuropean to win the Nobel Prize in literature in 1913, Rabindranath Tagore, 'I slept and dreamt that life was joy. I awoke and saw that life was service. I acted and, behold, service was joy.' " (Lawrence, 2015). The qualitative research included 16 interviews that were conducted to analyze the perceptions of participants who have worked with Lawrence in both the journalism industry, and the political and educational policy arena. Each participant who contributed to the research supported that Lawrence models servant-leadership traits.

Lawrence's leadership style sets him apart from other educational leaders because he models authentic servant-leadership as he advocates for the needs of the youngest members of society. Lawrence is identified by others as a child advocate and a real servant-leader. The Children's Movement is the platform by which Lawrence persuades others to join a greater cause and that allows him to push a selfless agenda. His advocacy and service to the most vulnerable and oppressed members of society is clearly defined by his ongoing actions to social justice for all children. Participants of this study willingly shared their experiences regarding their relationship with Lawrence. In addition, each participant shared anecdotes and described Lawrence's leadership traits without any hesitation. 


\section{Participants}

The participants of this study were all individuals who have worked with David Lawrence Jr. before, during or after his days at the publisher of The Miami Herald. The individuals are from four interest groups in Florida. The contingents were business leaders, political leaders, local South Florida leaders and educational leaders. The business leaders included Jorge Perez (Related Group), Mike Fernandez (MBF Healthcare Partners), and Carol Jenkins Barnett (Publix Super Markets). The political leaders interviewed included Senator Bob Graham, former mayor of Miami-Dade County Alex Penelas, statewide director Vance Aloupis from The Children's Movement and Florida Governor Rick Scott. The local South Florida leaders interviewed were Alberto Ibarguen from the Knight Foundation, Bishop Victor T. Curry from New Birth Baptist Church, and Dr. Judith Schaechter, the department head of pediatrics at the University of Miami. The educational leaders interviewed included Dr. Joe Greer, Florida International University’s Medical School; Joe Natoli, current chief financial officer from the University of Miami; Evelio Torres, current chief executive officer of the Early Learning Coalition, and Dr. Raquel Diaz from the University of Florida. A list of these participants appears in Table 1.

In addition to the recorded interviews, the researcher collected event speeches from David Lawrence Jr., field notes during each interview, and archival documents. The notes taken during each interview facilitated the identification of emerging themes. The researcher coded the transcriptions to identify reoccurring themes throughout the interviews and other data collected. 
Table 1.

Participants interviewed who identified David Lawrence Jr. 's servant-leadership qualities

\begin{tabular}{|c|c|}
\hline Participant & Role and link to David Lawrence Jr. \\
\hline Jorge Perez & Collaborated on multiple boards \\
\hline Senator Bob Graham & Politician \& publisher relationship \\
\hline Vance Aloupis & $\begin{array}{l}\text { Recruited as statewide director of The Children's } \\
\text { Movement }\end{array}$ \\
\hline Alberto Ibarguen & Successor publisher of The Miami Herald \\
\hline Evelio Torres & Collaborated with the early childhood coalition \\
\hline Dr. Joe Greer & $\begin{array}{l}\text { Friends since the 1980s when Lawrence moved to } \\
\text { Miami }\end{array}$ \\
\hline Dr. Judy Schaechter & $\begin{array}{l}\text { Mentored by Lawrence \& collaborated on several } \\
\text { boards regarding children's issues }\end{array}$ \\
\hline Alex Penelas & Politician \& publisher relationship \\
\hline Bishop Victor Curry & Community leader \& publisher relationship \\
\hline Joe Natoli & The Miami Herald days \\
\hline H.T. Smith & Community leader \& publisher relationship \\
\hline Carol J. Barnett & Early Childhood Initiative \\
\hline Raquel Diaz & Early Childhood Initiative \\
\hline Mike Fernandez & Collaborated in Mayor Penelas’s taskforce \\
\hline Rick Scott & Relationship from journalism days \\
\hline Jeb Bush & Early Childhood Initiative \\
\hline
\end{tabular}




\section{Servant-Leader Tenet 1: Listening}

A servant-leader chooses to listen to others in order to build healthy relationships. On July 9, 2015, at the Biltmore Hotel in Coral Gables, Florida, retired senator Bob Graham described Lawrence as a good listener:

David is humble. He is very quiet in his demeanor. Somewhat disarming with these qualities, but it also allows him to focus on the mission to be accomplished rather than how he might be given honor or credit because of the mission. He listens.

Listening coupled with reflection allows a servant-leader to understand personal strengths and weaknesses in order to lead and collaborate with others. On July 27, 2015, in his Knight Foundation office, Alberto Ibarguen shared that his experiences with Lawrence started in the field of journalism and later carried on into the present Children's Movement. Ibarguen described Lawrence's ability to listen to others' opinions:

He listens to what others think. I think that's what you do with weaknesses; when you work around your own weaknesses. He is not somebody who's going to be as good as others at working Tallahassee. Vance [Aloupis, state director of The Children's Movement] is the kind of person who can smoothly work that kind of a setting. Dave recognizes his weaknesses, he recognizes his impatience, he still drives, and he doesn't make an apology for it. He works as hard as any man I know. I will tell you that I don't take a backseat today or anybody else in terms of, of work and in terms of passion for work, and in terms of hours worked. I have the physical energy for work but I don't pretend I work harder than Dave, because no human alive does. [laughs] 
Herein, Ibarguen clearly illustrates that Lawrence listens to the opinions of others. His hard work is not compromised in spite of the perception someone may have of him. He listens and recognizes truths spoken by others. His ability to listen to others has provided him a venue of ongoing success and retrospect for his own leadership development as he makes necessary changes for the growth of his mission.

Lawrence has modeled the tenet of listening throughout the years. Bishop Victor Curry, on August 5, 2015, during the researcher's visit with Curry at his church, described the servant-leader actions of Lawrence with the African-American community: Well, it probably goes back to when he was the publisher of The Miami Herald. That far back and that was our first time meeting him, probably meetings about The Herald and sometimes how the African American community was portrayed in The Herald back then.

What could have been a contentious kind of situation, the one thing about David Lawrence, in my opinion, he's just honest to the core. He's just, you know, it never got to the place of being contentious because that wasn't the tone; he wasn't defensive. I think he genuinely was concerned about the entire community and how his paper was looked upon. Dave is a consensus builder. He's a bridge. He is inclusive. And his approach to leadership that I've witnessed firsthand, he'll bring everybody to the table, doesn't matter your background, your ethnicity, and he does that in order to build consensus, to build unity within our community that is very, very divided in certain areas.

For the most part, we have a tendency, and that's every neighborhood, we talk at each other, but we seldom talk to each other. David was one of those people who 
brought us together to talk to each other instead of at each other. And I think he did that through The Miami Herald and certainly did that through The Children's Trust and early childhood development. Lawrence brought people together to talk to each other.

Curry stressed the necessity of bringing people together. He explained throughout the interview that Lawrence in fact did just that -- uniting a fractured community both as a publisher and as a servant-leader. As Curry described Lawrence, the consensus-building attitude made all stakeholders believe that their voices were being heard. The attribute of listening as a servant-leader allowed strangers to come together and start building relationships. Although Curry described how attentive Lawrence was about paying attention to others, he stated that Lawrence was not a passive listener. Lawrence was seeking positive changes that would be fundamental for building a stronger community. As found throughout the research, Lawrence demonstrates multiple characteristics of a servant-leader in any one given situation. All the traits are equally important, but Lawrence demonstrates that an exemplar educational leader may have a unique influence to make a community a better place.

\section{Servant-Leader Tenet 2: Empathy}

A servant-leader has compassion and demonstrates care for others by his or her actions. A servant-leader has good intentions in addressing and accepting others. On July 27, 2015, in his office in the United Way building in Miami, Florida, Vance Aloupis described Lawrence as a man who is fair to all people. He works in a fashion that makes all people feel valued. 
I don't think there's anybody who is more responsive than Lawrence. In a society where we're so instantaneous, we crave instant gratification. Lawrence believes in connecting with people. I think we've lost that in society. He makes sure he tries to feel what another person is feeling, whether it's through an interviewing process or just sorting through life.

Aloupis repeatedly shared the empathy Lawrence displays toward other people. His attitude of compassion has been witnessed by Aloupis in the mundane actions and words that become extraordinary when empathy is the trait demonstrated. Lawrence intentionally follows up with people to let them know he values them whether through an email message or mailing a book with an encouraging note sent to the recipient.

The way Curry shared his perspective regarding Lawrence's attitude about diversity was a clear indication that Curry perceived Lawrence as an empathetic leader: He's a leader's leader, but he leads by example. I don't think David has a malicious bone in his body. And I think his motives are pure. And I think leadership is influenced by influence, and he has that influence. And I believe people gravitate to him because of his sincerity, and because of the fact that he doesn't have any ulterior motives. He's straightforward; how he feels is how he feels. Whether you agree with it or not, and... I think his approach is that of a gentle giant. He is well-respected, and I think because of that people gravitate to him and will follow him. I'm a big David Lawrence fan, period. There's no other way of putting it. If I could have brought in a big old foam finger, I would do it; that's how much I like David Lawrence. 
Two words: passion and compassion. He's passionate and what I think drives him is his compassion to help the least, the lost, and the left out.

(Bishop Victor Curry, personal communication, August 5, 2015)

Curry emphasized that empathy is a trait that Lawrence has displayed throughout the years he has known him. The differences that divide cultures and communities within society become a potential strong point for war unless empathy is the tone used to address the matter. Lawrence places himself in the position of others in order to better understand and acquire wisdom to help people. His compassion as described by Curry makes him an empathetic servant-leader as he influences others.

\section{Servant-Leader Tenet 3: Healing}

A servant-leader by nature of the tenets identified by Greenleaf helps others heal and grow to become better people. Sometimes the recipient of the healing isn't aware of the power of the servant-leader until reflection allows for a deeper understanding of the leadership qualities shared with others. Aloupis described his experience with Lawrence:

I met Dave at Coral Bagels in June 2010...it was probably one of the most transformational moments of my young adult life in that I came out of the breakfast realizing how little I actually knew. You are a young attorney; you go to a good school; I had done, achieved some things, what I thought were important benchmarks. Thank God it happened when I was 26 years old, not when I was 46 years old. I realized there were a number of things I needed to learn. (Vance Aloupis, personal communication, July 27, 2015)

Everyone has areas of weakness. As Aloupis described, his weakness was pride and arrogance that he was indeed an overachiever. Aloupis explains how his self-awareness 
as a result of time with Lawrence prevented him from future emotional ailments that would need future healing. Aloupis shared that Lawrence's qualities served as a remedy for his self-pride, because Lawrence gently refocused his perspective from self to others. Aloupis shared how Lawrence has been a mentor who has provided ongoing encouragement in his young professional years in order to better serve the needs of others. Many adults have deep hurts and insecurities that carry over to other areas of their life. Caring for others allows individuals to heal from emotion hurts in order to become better people in a society, so that less high-risks and poor choices are made during adulthood.

Pedro "Joe" Greer has known Lawrence since the 1980s. He shared his experiences with Lawrence during the interview on July 29, 2015, at his office in the Florida International Medical School building. He described Lawrence's leadership traits as follows:

Dave's leadership is that he can lead because of his successes and his successes are dependent upon both the fact that he is so mission driven, he is for the public good. He was brought up that way. He is deeply faithful in his religion, and he truly believes that we are supposed to stick up for the least of our society. Dave's leadership style has been completely inclusive as a leader. Lawrence doesn't need a parking spot that says chairman because he is going to get there before anybody else anyways. So he can pick any spot he wants. He is also going to leave later than anybody else. He is also going to respond to every single person. As the publisher of The Miami Herald, he used to answer his own phone. Dave responds 
to everybody. I would characterize him by the line from Rudyard Kipling's poem

"If." If...you could walk with kings and not lose the common touch...”

Lawrence as described by Greer is a man of humility. His passion for public good stems from the premise that everyone has a story. Healing the broken pieces of humanity is related to the desire of serving others without judgment. Lawrence seems kind to everyone he meets and chooses not to intentionally add hurt to the life of others by treating each person with respect and dignity -- Greer goes on to say that:

Dave has a way of fitting right into wherever he is- whether it is -- with the presidents or the heads of states, or it is with the person that is cleaning the floor. Dave will treat both the same with equal respect. He is also smart as hell, but I can tell that he is not driven by any ego. He is driven by mission and deeply faithful to it.

Greer clearly described Lawrence's desire to bring healing into humanity through his kind and humble spirit, rather than using his influential position in society for his own ambition. Lawrence is described as a respectful and gentle man when addressing others regardless of their position or social class. This explanation of Lawrence's demeanor brings value to others which in turn builds and encourages others, even when they are unconscious of the process.

On August 8, 2015, in his office in Miami Lakes, Florida, Alex Penelas explained the importance of child advocacy for Lawrence. Lawrence's action of advocating for all children by default provides ongoing healing to society.

We all should be child advocates especially if we're parents, right? And obviously I spend a lot of time and effort advocating for and taking care of my own kids and 
I should... no one needs to give me a ribbon for that, but he's done more than that—he's been a fantastic father, grandfather, and what makes him different is that he is advocating for everyone's kids. That's what makes him different. What he is doing doesn't have anybody's name on it. It has all the kids' names on it. That's what's—-that's what's amazing.

Well, he believes all children have the same inalienable right and opportunity to get a head start in life. That's what he believes. So when you believe in that, you don't pick and choose. You don't say, "This one: Yes, and that one: No." If you believe in the greatness of opportunity, in the greatness of this country then any child, in spite of his circumstances, if given an equal opportunity should have, you know, an opportunity to excel. And that's what he believes in. That's what The Children's Movement is all about.

The caring for others may be an instrumental part of the healing process. When a leader chooses to serve the needs of others and build a relationship, pending hurts may be discovered and healed through the positive human connection. In order to further understand matters of children and family in our complicated society, listening and intentionally helping others may be part of the healing process of humanity. Penelas emphasized and identified the desire Lawrence has to care for all children and every child. His emphatic tone suggested that not all leaders have the same desire to help others the way Lawrence cares for all children.

\section{Servant-Leader Tenet 4: Awareness}

A servant-leader reflects and becomes aware of strengths and weaknesses in order to accomplish the greater purpose. Aloupis described Lawrence as an extraordinary 
leader who is aware of what has given him an edge on his ability to succeed. Lawrence's awareness of self also provides an example of the empathy he exhibits toward others: His integrity...honesty.... I think, the first one which is responsiveness, which also speaks with integrity, which speaks to genuine... compassion for other individuals... core values of just work ethic, his hardworking ethic. Realizing that so much of the reason Dave has been successful in life is because he can outwork people. It's not that he's particularly brilliant. He's very, very smart, but he has an ability to outwork people. And he'll tell you that. He can outwork anybody. At the end of the day, I would much prefer to go up against somebody that thinks they're smarter than me than someone who thinks they can outwork me. I think we oftentimes underestimate the honest power of just good hard work and the ability to pound the pavement more than anyone else. So... I think that's essential. (Vance Aloupis, personal communication, July 27, 2015)

Lawrence has shared with Aloupis that his hard work is one tenet that supports his success in life. His awareness of the work ethic that drives him has provided Lawrence with an understanding of the outcomes that follow hard work. Lawrence identifies his own strengths and weaknesses.

Awareness is another element of a servant-leadership because it enables trust to be built between the leader and followers. When a leader recognizes his or her own shortcomings and strengths, he or she is better equipped to give insight to others who are seeking success. On July 28, 2015, in his office in Coral Gables, Florida, Evelio Torres explained: 
Dave ... compassionate... he's a good leader. People follow Dave because he is a man of integrity. Dave is a person with a lot of integrity and, and Lawrence will tell you things that you may not want to hear, but he's going to tell you things as he sees them. And people believe in Dave and when people follow a leader, it's because they see something in that leader that they believe. They can sort of attach themselves to as a human being. And I think those are his leadership traits. People trust Dave. He's not a perfect human being—God knows—but... people trust him and follow him generally. He's not perfect. But he serves others because he is aware of the value of service.

As Torres mentioned several times, Lawrence is not a perfect man. He demonstrates good qualities as a leader and people respect him. He is perceived as a man with awareness of self and others. His servant-leadership traits serve others and bring awareness to the purpose of service.

I don't know if you agree with that or not, but he'll be the first one to tell you that he is not a, a perfect person. And Dave will...come back and say, "Hey," you know, "can we talk about what happened?"

Torres mentioned Lawrence’s awareness to revisit decisions and actions. Torres described Lawrence as a man who can apologize because he is aware of his words and actions. Lawrence doesn’t allow pride to prevent him from correcting erroneous actions. His awareness is refreshing to others.

\section{Servant-Leader Tenet 5: Persuasion}

The art of persuasion is not coercing compliance. Persuasion influences the decision others make without using fear or claimed power over another. Persuasion 
motivates and inspires others to make decisions that support the mission of the servantleader. On July 30, 2015, in her office in the University of Miami medical facility, Judy Schaechter described Lawrence's actions and persuasion:

Dave is definitely a big-tent man. He brings everyone in who wants to be there and who should be there. And he'll convince people to be there if they haven't figured that out and should be there...he's extremely consistent about his fabric which is ethical, he genuinely cares about people, his community, who we are and who we want to be... and he doesn't see that as a long distance. Who we are now and who we want to be... where we want to go... but he really gets you to believe that we can get there and we all need to be there together... and his communication skill about, how everyone in the room has a responsibility to get there and wants to play a role in being part of that movement is... phenomenal. It works every time.

Lawrence invites people to come together. He is described as a "big-tent man” with an intentional purpose. He is on mission to persuade others to join his cause to serve the early childhood needs of all children. Lawrence uses specific words to support his argument in convincing others.

Investing wisely in the early years, and believing in all children, we help all of us. It simply makes sense -- practical, economic and moral --to be mindful of how everyone is doing, and to give to every child the opportunity to fulfill his or her potential. If we want less crime, if we want more people to grow up to own homes and cars, and more people to share the basic costs of societal well-being, then we should know of the quite extraordinary evidence of the power of early investment 
and the power to grow children who dream and have a real chance to achieve those dreams.” (Lawrence, 2015)

Lawrence uses persuasive argument in the pursuit of his mission to serve. Lawrence assertively motivates his audience and pleads the case of caring for all children. His argument makes common sense and his leadership is true to the cause, this makes him credible and trustworthy to others.

On June 24, 2015, in the Related Group building in downtown Miami, Florida, Jorge Perez explained the gift of persuasion of a servant-leader:

Dave has been extremely good because he has credibility to convince a lot of people -- politicians, and businessmen and so forth -- which perhaps were not thinking about early childhood education, about the importance it has for children from very early on who don't have the tools to develop into complete human beings. He is a great advocate of that, and he has been able to get people's attention and people's money.

Perez clearly describes that Lawrence has persuaded many people from all walks of life to join his mission. His passion for early childhood has resonated with his ongoing argument that it makes sense to invest in early childhood education. Lawrence quotes others like Lilian Katz, an early childhood education advocate, and persuasively challenges others to embrace in your mind and soul that the welfare of our children is intimately linked to the welfare of all other people's children. When one of our children needs life-saving surgery, someone else's child will perform it. If one of our children is harmed in violence, someone else's child will be responsible. The 
good life for our children can only be secured if a good life is secured for all other people’s children. (Lawrence, 2015)

Joe Greer explained Lawrence's position of persuasion. Greer described Lawrence as inclusive, and that is how he influences and persuades others:

He leads by example. In other words, Dave leads in the right direction and not for what his ego wants but for what is the best for everybody. He is not afraid to make enemies when it's for the right reason. He never looks for a fight, but he wholeheartedly believes in the truth. Truth is not relative. Truth, it has to be evidence based. That's number one. There are certain things that are not truths but missions and beliefs, for example social justice and the care for the lesser of our society. That's not a truth, but that's based on faith, ethics, and morals, which come from faith. So you know that's a separate thing, but apart from being driven by the truth he is driven by ethics and morals. (Joe Greer, personal communication, July 29, 2015)

Lawrence is consistent about his position regarding the social truth and uses that in his arguments to persuade. Lawrence also grounds his persuasion in ethics and morals. His message includes making early childhood education a priority for everyone. Lawrence explains that "Americans need to respect and get with the reality. Every American gains when we give everyone a real opportunity to succeed. That is not social engineering but rather essential for a moral and optimistic America.” (Lawrence, 2015) Greer contributes further to this aspect of Lawrence:

I mean you could blindly follow the truth—you know, without understanding all the other things that go along with it that actually does not make it true, but Dave 
is not that way. Dave is the best-read person I have ever seen in my life or ever met. He is the best writer and speaker I have ever seen, but that's because he can take the experience from thirty thousand feet and still understand what it's like to have boots on the ground, and that's not a very easy thing to do. Some leaders work very well with thirty thousand feet. Dave works well with the ground on up. Dave actually knows everybody's name regardless of what position you are in life, and he's not afraid to say what he believes, and he always does it in a very respectful manner because you don't have to agree with everybody. You just have to be respectful, and in this town that's not always easy. (Joe Greer, personal communication, July 29, 2015)

Greer described Lawrence's gift of persuasion. In particular he sees that Lawrence is grounded in the realities of ordinary people in spite of his influential position in society and does not look down upon people but rather redirects the perspective of others to see the greater good in others. Lawrence is described as a leader that does not put himself above others. He is a man with characteristics of a servant for greater good.

Alex Penelas explained Lawrence's ability to persuade in this manner:

Dave is not a partisan man. He has been able to influence politics because first of all, he is a man of great standing in the community—if you're running for governor- He's someone you want on your side. He has the credentials he's built up in this field—he's the go-to person for a lot of elected officials and policy makers. That puts Dave in a very influential position because not everyone offthe-streets gets to share his or her opinion with the governor or president on 
important issues. And he's done that—he's been very ethical, you know, very straight, very apolitical, and he's earned this position.

(Alex Penelas, personal communication, August 8, 2015)

Each participant explained that Lawrence is a man of integrity and credibility. These core values that drive Lawrence's servant-leadership style give him an advantage in persuading others to follow his mission to serve all children. His servant-leader traits collectively influence policy makers and other community leaders.

\section{Servant-Leader Tenet 6: Conceptualization}

Servant-leaders nurture their own ability to dream great dreams. A visionary becomes a missionary to the dream in order to make the dream a reality. Conceptualization makes a dreamer a realist upon completing the mission at hand. Ibarguen identified Lawrence's ability to meet operational goals as a missionary seeking to change the value system of a society regarding the needs of children. Ibarguen explained that Lawrence showed him the value of the return on investing on early childhood years.

Dave is consistent. I should say even more persistent. He is just tenacious. It is a mission with him. He told me one time -- I forget what the issue was -- and he said, "You know, Alberto? There's some missionary in my personality." And I said, "Really Dave? I hadn't noticed that?" [laughs] I said, "Oh, please! [laughs] Tell me the sun rises and sets and we got that, and yes, there is some missionary in your personality [laughs]."

Dave is a missionary. He believes that there was this hole in the system that had enormous negative consequences... thousands and thousands of children who 
were not getting either the right nurturing or the right education or the right opportunities. He believed the data that he read that was not developed by him but by others, that suggested you don't take care of these things in early ages, the cons - the societal consequences are really deep and significant. I think he just, from his own experience, has seen enough people who had been hampered early on that he felt were good and worthy and could have contributed far more. But mainly, he just, he does not take things lightly. (Alberto Ibarguen, personal communication, July 27, 2015)

Ibarguen alluded to the fact that Lawrence identified a hole in the social structure of education, and Lawrence had an attitude greater than self in regards to community service to fill the hole. This servant-leader trait or as Ibarguen described "missionary" characteristic continues to drive Lawrence to advocate for all children and every child since the time he understood there was a gap in the system.

Schaechter described Lawrence's leadership as inspirational. She explained that Lawrence leads by example and he encourages people to see the best in themselves. This approach by Lawrence motivates them to want to reach higher ground.

Connection to each other, believing that things can be better, will get better. Not getting stuck... in... the Shel Silverstein's: should've, wouldn't've, couldn't've, won't—you know? Dave certainly knows about limited resources, which, you know, those of us in education, in child advocacy, we know this world, but you can't get stuck there. And so bring people together, understand the principles. And help them see the way and believe in that, and things do happen. I mean he has a whole list of accomplishments. Give credit, share that credit, right? He is so 
smart about explaining what our situation is in clear ways — so in the paper this morning, right, 30 percent of our children are living in poverty.

So, but he, Dave, will use that and a bunch more, and he somehow, when he speaks to people, he'll take them to higher ground so that they will find a way, whatever their way is_-whether that's giving money or volunteering or writing something or changing the viewpoint of someone who used to blame those parents or those kids or those people who worked with those kids or whatever it was. And... uplifts those of us who do work with those kids. (Judith Schaechter, personal communication, July 30, 2015)

Instead of blaming others Lawrence conceptualizes what society should and could be. He takes what seems to be an idealistic mission and then breaks it down into tasks and goals to be accomplished thus offering a practical approach to finding a solution. Lawrence gathers others to join the mission of advocating for all children and leads the movement consistently.

[he says] Those kids are our kids. And that's very clear-It is always a unifying message. It's all our kids. I'm equally committed to that because there is not a child out there that does not go through hard times. There are lots of Dave-isms. He walks the walk and talks the talk... there aren't really inconsistencies. Now I can't tell you that he's not one of those people that...other people talk about, other folks in leadership, and say, "Oh, I've never seen him angry." That's not true. I know he gets angry and has real emotion, right? And I know why he gets angry and has real emotions. I know that he can also control that if he wants to, right? ...but it comes out because he cares. That, to me, is authentic. And I know the 
issues he cares about. I know he completely cares about people. (Judith

Schaechter, personal communication, July 30, 2015)

Lawrence is described as a consistent leader who cares about others, Lawrence has a mission to help all children and he voices his advocacy without reservation. His mission to help all children may be misunderstood at times when he expresses his discontent with "the effects of inattention to the early years of childhood" (Lawrence, 2015) with a harsh tone, but those who know him explain it is because Lawrence is a caring man and harsh tone should not be misinterpreted for anything but caring.

Dave-ism...it's like a WWJD... I-I often think a WWDD, you know: what would Dave do? It's easy to figure out what he would do in situations. He's very, very consistent. And I am Jewish. I am not going to put Dave up on a cross. He is a real human being. He is a mentor. I am old enough to know that real people have real flaws. So Lawrence is no Messiah, but I admire him as an extremely ethical person. I have had disagreements with Lawrence, but I understand his thinking. (Judith Schaechter, personal communication, July 30, 2015)

Lawrence conceptualizes a dream in which all children are assured of an advocate. His ability to be consistent about his day to day work to achieve this mission brings together people from different walks of life. He takes every opportunity to help children to a better future. Lawrence was described by the participants as a practical leader with eyes wide open to the needs of all children.

\section{Servant-Leader Tenet 7: Foresight}

Aloupis described Lawrence as a leader who models foresight and an interest to share his wisdom with others: 
I think Dave transcends communities. I have never seen anybody who can talk to so many different kinds of people. The words he uses are so deliberate. But very few people I know can speak to the left-wing organizations, the right-wing organizations, the organizations that are right down the middle, and leave them, you know, coming away in the sense of "I want a piece of what that man is building." I have seen him do it all over the city. He does it all over the country. That is a unique ability that I think he has. (Vance Aloupis, personal communication, July 27, 2015)

Lawrence has foresight. He understands the possible outcomes that follow his decision making and words spoken. Lawrence is intentional about his purpose to serve all children. His particular characteristics as a servant-leader transcended from his journalistic career to his involvement in education. His apolitical tone confirms that building others and building children is a bipartisan cause.

Ibarguen shared insight of Lawrence's leadership and his shift from journalism to education:

Then the world changed. And I will tell you because I was there. Dave is the guy who hired me to come to Miami to work with him. I was literally sitting right next to him as all these things were happening. Really, really good leaders, I think, have an ability to step back and say this is where I can move forward. And, I would tell you with enormous courage, that after a lifetime in that business, Dave decided that what he knew how to do and knew how to do so well... where his skills and energy and passion, which are considerable, could be employed. So, what are the things that always run through Dave? He is not motivated by money; 
he is motivated by mission. In one case, the mission was to inform community. In another case, it's a mission to, cares for and educates and nurture children as a way of creating a better community. (Alberto Ibarguen, personal communication, July 27, 2015)

Lawrence was described by Ibarguen as a man with great foresight. The strengths that made his publishing days successful transferred to making a children's movement possible where it seemed impossible.

In both cases, it's a way of creating better community information and caring of children. I don't mean to say Dave is a monk—he will take the nice paycheck, not a problem—but his drivers have never been money; his drivers have always been mission. How do we get from A to B without sugarcoating? So the journalistic function of discovery and coolness of assessment of that data is one of his core skills, in my view. He has vision... somebody else looks at the same data and says, "We're in a heap of trouble." He looks at the data and says, "I think I can get Miami-Dade County to vote itself a tax so we can have some money to approach this thing." Everybody else says, "Dave, you're crazy. Dave, this can't be done. Dave, nobody in this, in this time and place is going to vote an extra tax, especially when you're not talking about something specific...People are very, very suspicious these days, I think they always were of government, but, you know, especially now, people are more able to express that these days with social media like never before. (Alberto Ibarguen, personal communication, July 27, 2015) 
Along with Lawrence's ability to have foresight, he is not discouraged by a challenge. Instead as Ibarguen described, Lawrence's growth mindset takes a problem and pursues all possible solutions.

Yet, this guy decides, we can do this, we can do this in a measured campaign. We will, we will begin the program, we will raise some private money, we will do some things, we will show that we will do the logical, "Oh, we gotta go from zero to 100 in 30 minutes." No, you can't do that. You've got to do the prototype, beta, and then scale - and that's what he did. And make the promise, and then get on TV and say, "We promised you this and we delivered exactly." And people can then say, "Okay, I get it." And explain it simply. Dave is nothing if not absolutely clear in his communication. He has got the vision to see what could be. He's got the courage to put himself out there because I'm telling you, I actually remember having conversations with people and telling them, "Look I don't know anything about early childhood readiness, but I know a lot about Dave and I would bet somehow this is going to work. I don't know exactly how it's going to work, but I bet you it's going to work. He's got the courage to put himself out there, doesn't matter that people don't see the same thing. It doesn't matter that people even don't, even don't agree. (Alberto Ibarguen, personal communication, July 27, 2015)

This interview confirmed how the servant-leader uses the power of influence to make things happen. Lawrence's motive to drive an agenda other than a selfish one is greater than the short sighted vision of others. Lawrence is a man with foresight. 
On August 12, 2015 in his law office, H.T. Smith shared examples of Lawrence's foresight and influence within the South Florida community.

Lawrence can see it before it happens, understanding as the expression goes, that most... great... projects, ideas, start with looking, appearing to be, impossible. So you are talking about having the people in Miami-Dade County tax themselves for a trust for children. That's not happening. Lawrence said, you know, it's absolutely necessary and it is absolutely doable if we come together and first, listen to the people. And second, demonstrate from the people what they will get out of the deal either directly or indirectly. Three, demonstrate that The Trust can be trusted as stewards of the people's money. One of the smarter things he did, when he first he had the people of Miami-Dade County to tax themselves for the trust. He says, "Okay. We just want to do it for five years. See what we do. See how we do it. See if we're transparent. See if we're meeting our goals. And see if this is something you can be proud to continue, to invest your tax dollars in. And if not, it's over." Brilliant.

Lawrence is described by Smith as a man with brilliant foresight to realize his dream by first building trust in the community. Lawrence invited taxpayers to evaluate the effects of funds used and then revisit the taxation. .The community was able to trust Lawrence after the initial funds were used appropriately. Smith continued:

Very few people could have done that because if-just for the work and the anxiety that people, you know, can kind of get better, whatever, man, peopletaxes are way too high, and so it's that kind of visionary leadership and creativity—so he's visionary, he's creative. Lawrence also understands something 
most leaders do not in our community. Most leaders see diversity as a requirement but not necessarily as a benefit—understanding that excellence is the flip side of diversity because if everybody is in the pool of candidates for contributions, you got a much wider base of talent to pick from. Not just men, not just whites, not just Hispanics; in fact, everybody's in the pool! So you can get the best talent if you really believe that there is talent in all the tribes. I like to talk about the tribes and all—and there is! And he is smart enough, too. And another thing is, he is a great talent scout. He can, and so he can identify talent and he can put talented people in positions where their strengths can be maximized. For instance, I have been a leader, but don't make me a secretary of anything. And lastly, David Lawrence is one of those leaders who people who have talent want to work with David Lawrence... One, because he is so talented; two, because he respects your contributions; three, because he will listen; and four, because he is impeccably honest, and five, because he is always trying to improve the quality of life in our community. You know, so people can buy into that. And people do buy into that. And that's why he is a community treasure. Not just a leader but a treasure. And, you know, I don't know about you, but I have my treasure in the safety deposit box.

On August 6, 2015 at the University of Miami, Joe Natoli had a meaningful story regarding Lawrence's actions and foresight that ultimately inspired him:

Dave came into town in about '88, no-yeah, about '88, I think. And so I first heard of Dave when he was a publisher for the Detroit Free Press and it was the worst-kept secret in the world for about the last year that he was going to become 
the publisher of The Herald. So we all knew this guy was coming and we were all hearing about him and he was, he had quite a reputation for being an incredibly hard worker and very demanding. And so, I met Dave when he was announced finally. I remember he called me at my home one night, right after he was announced, and, "Hey, Joe, this is Dave. What are you doing?" And I think the Detroit Pistons were in the NBA playoffs at the time and Dave was a big sports fan and he was watching it, and my answer was-he could not understand why I was not watching the NBA Playoffs. So that's how I met him.

I met him when he first, when he first came to town. Dave had only been in town for a few days when we did our retreat in the Keys. And what I remember about that was, was the management team and our spouses or significant others, and what I remembered was that all through the dinner, Dave rearranged where people were seating. So whoever was sitting next to him, he says, "Okay, you go sit over there." And he went to my wife, Jennifer, and said, "Jennifer, you come sit over here." 'Cause he's very inquisitive about people. That's how he gets to know people.

So Dave had only been here a few months when we ran into him at dinner one night; so I didn't know him well at the time, and so we were eating at an Italian restaurant, what was then the Bakery Center, so this is what is now the Shops at Sunset was the Bakery Center. And we're there, and it's my wife and my two young children at the time and, I say, "Hey, there's the publisher over thereDave, his children, and Bobbie." And so I said, "Let me just go and say hi." And so I walk over, and it was a Saturday night, and said, "Hi, how are you doing? 
What's going on?" And he looked up at me and said, "What'd you do today, Joe?" And I said, "Slept in, got up, read the newspaper, played a little basketball, took a nap, went to the movies, and here I am." And there was this sort of awkward silence. And I said, "What'd you do today, Dave?" "I went to the office, I spent the first, the morning at work," which he did, he always did every Saturday morning, he worked half a day, "then I went to Camillus House where I spent the next several hours with the homeless, then I gave this speech at this other place." You know, it was a full day of work and community service. And then he looks up at me and he goes, "What are you going to do tomorrow, Joe?" I remember saying, "I guess if I say 'nothing' again, this is going to look pretty bad, right?" And he said to me, not actually in that moment, but another time later, he, he said, "If on your tombstone it says, "Here lies Joe. He was a great business executive,' what a sad life you will have had, right? When there's the opportunity to really make a difference." And that— that really got me into community service and I subsequently led the United Way campaign everywhere I've lived and done all sorts of things like that, but I really got into that because of Dave.

Lawrence's Socratic approach of questioning others is evidence that he both selfreflects and leads others through a self-reflection process. Lawrence's goal of the reflection process leads to foresight so as to identify the greater needs of the youngest members of society and the humanity of social justice.

\section{Servant-Leader Tenet 8: Stewardship}

The concept of stewardship in a servant-leader assumes first and foremost that the commitment to serving the needs of others is a priority. In this research, stewardship is 
identified as openness and persuasion, rather than control, directed to improving the lives of all children. Torres explained as follows:

He is all about the children... particularly early education, health and everything else. Obviously, he's focused on early education. Dave just wants... all the kids to have the same opportunity in this country. And when he travels he keeps reminding everyone that this is not about creating a real fancy school with all of the gadgets, all of the bells and whistles. You can have a very high quality program under a tree. I saw it when I went (with him) to Hawaii, and he's seen it in a number of countries that he's visited. It may not be a very fancy setting, but you have really good teachers that are dedicated, and there is some parental involvement also. And that goes a long way.

Serving others begins at home, but sometimes the community has to step in to help the family. That is the message Torres shared that Lawrence takes all over the world.

The American standard, in terms of a very fancy school with all that... when you look at areas in Miami-Dade, for instance like Liberty City-Liberty Academy in the middle of ... drug house ... two telecommunication executives took a chance, bought it, turned it into a childcare center, and it's an amazing school. And it's a beautiful school and it just gives you hope. Now, their school is beautiful, ... but you know it didn't start off that way. It has been a work in progress and they recognize that. ... and it's great so... I think Dave is very focused on helping to create a lot more of those situations.

Torres explained the how Lawrence is a good steward for all children. His mission is to help improve social challenges by investing in early childhood readiness. 
Dave has done several things to advocate for all children (1) establishing and being so involved in creating, — the early learning coalitions. ...(2) the School Readiness Act of 1999—VPK, which came into being in 2005 ... the creation of The Children's Trust and the reauthorization; (3) creating The Children's Movement of Florida; and (4) it's politics at the end of the day, or a lot of it is about politics and the impact that's having.

Dave hasn't always been kind when you read those blasts that go out. When the governor steps out of place, Dave calls him out on it. Dave has created an awareness that wasn't there before with the business community. He has the Council of 100 also, which are business leaders. So those are probably like five or six major things that Dave has really been instrumental in. And I would say that he's led most of those. (Evelio Torres, personal communication, July 28, 2015) Torres mentioned that sometimes being a good steward and serving the needs of the oppressed may not be a passive position. Torres described a man named Lawrence that in the name of children may speak with a tone that seems harsh. Torres elaborated that sometimes the truth may offend and Lawrence has no reservations in standing by the truth when it comes to children.

Graham described Lawrence as a person with clear servant-leader traits: I would describe him as a treasure for our community and the world. He has the combination of genuine compassion, which is not just episodic over a particular event. His compassion is grounded in pragmatism. He has clear vision of what can be done to make the world better in the space in which he is operating. He is a 
man of distinct character. He has a set of values you can rely upon. (Bob Graham, personal communication, July 9, 2015)

Perez repeatedly described Lawrence as a do-gooder:

Lawrence is a do-gooder about everything he is involved with. When he was a newspaper man, he put content over profits, I think, transparency over politics and backroom shenanigans. He was very clear about his opinions and stated them even though sometimes created adversaries, and he went against the grain. I remember an example of a situation with a very powerful influential leader in Miami that did not see eye to eye with Lawrence regarding the relations with Cuba. Lawrence published what he thought was right, as opposed to what those people in power expected. He always did what he felt was right. When he sets his mind to do something that he feels is right, he is very passionate about it. (Jorge Perez, personal communication, June 24, 2015)

\section{Servant-Leader Tenet 9: Commitment to the growth of others}

Ibarguen described Lawrence as a man who is committed to the growth of others and it being a central concept of Lawrence's mission at hand. Ibarguen explained how Lawrence identifies and helps build up others for their greater good, through a vision that people may not see until the vision becomes reality.

In that function of a teacher maybe he's great, but he doesn't really have the patience for bringing along a student, particularly, unless the student is working just as hard as Lawrence does, and that's usually pretty hard. He has the capacity to not know what he can't do. And, ,...he'll go out and find people like Vance Aloupis who does a job that Lawrence theoretically could do and 
temperamentally suited to do. He's got the ability to go out and identify that, that first journalistic discovery, identify the other things, and then figure out, "Okay... you do this and you do that. Vance, you do this; somebody else will do that," and put the team together. Then, perhaps, most of all, he's got tenacity. He is like a dog with a bone. He will not let go. So, I will tell you: discovery, vision, courage, know-how and tenacity. This man has it, has them in spades. (Alberto Ibarguen, personal communication, July 27, 2015)

Although Lawrence has a journalism background, not a background in education, he is described as a man with a growth mindset that brings out the best in others if they are willing to work under his leadership. Lawrence is described as holding himself and others to the utmost standards to make the world better for all children. Lawrence is inclusive in his leadership. He is open to include everyone in the mission, yet he will not use coercion with individuals who do not share his vision and hard work. There is urgency in the matter of children's well-being and Lawrence has no time to waste.

One anecdote that describes a compilation of the servant-leadership tenets, including that of commitment to the growth of others, was evident on November 4, 2015, when for the first time Lawrence met a young mother from Massachusetts with her 6month-old baby girl. Before meeting with this new mother, Lawrence made his rounds to several customers who were having breakfast at a local and unpretentious bagel shop. Lawrence, a regular customer at this bagel shop, has used this humble establishment for meeting with people since he moved to South Florida in 1989. Lawrence sat at a booth and met with the young woman and her baby. 
I witnessed Lawrence asking this young mom probing questions about her life. When the mother shared she was originally from Ocala, Florida, Lawrence made an immediate connection by sharing his familiarity with her hometown. Lawrence's foresight allowed an instant connection with this woman. As she continued to share her story, Lawrence kindly said to her, "Thank you for sharing and being vulnerable. You are a good mother. Your baby is lucky to have you, but not every child has a mom like you." Their conversation lasted about an hour. At the end of their breakfast meeting, Lawrence reminded the mom the value of a greater good for humanity and persuasively reminded her that decent people need to think about the needs of all children.

This encounter between a young mother from Massachusetts and Lawrence was a culminating moment in this research. In a brief breakfast meeting with a stranger, Lawrence embodied the 10 tenets of a servant-leader. He actively listened to the new mom and her and her baby's needs. The mother nursed her baby while meeting with Lawrence. Lawrence was empathic about her new role as a mother. He provided a healing word as he encouraged her by acknowledging her vulnerability in sharing story of her broken childhood. The young woman told Lawrence about her childhood and how she related to the story of Cinderella with the wicked stepmother after her real mother died. Lawrence's general awareness about the needs of others allowed him to connect with this young mother naturally. Lawrence wrapped up the breakfast with this woman, paid the bill, and was able to build consensus with her regarding the value of every child. He shared his vision and mission for every child as he related to this young mother and her baby girl. 
Aloupis confirmed the Coral Bagels experience when he described Lawrence's typical moments of connecting with others:

I can't think of anybody I know that spends more time having breakfast at Coral Bagels with the kid who is just about to graduate from FIU figuring out what they want to do next with their life...His willingness to sow into [invest in] each individual person with an authenticity that you cannot find (elsewhere). He finds the time and has the willingness to find meaningful time in the day to mentor people of all ages, from eight to 68. It's incredible. I have been really amazed by his ability to achieve. (Vance Aloupis, personal communication, July 27, 2015) Natoli shared numerous anecdotes about Lawrence that illustrated the tenets of a servant-leader. One specific story to the commitment to the growth of others was explained in the following incident:

When I first started working for Lawrence, when he became the publisher of the Herald, I was the head of production for The Miami Herald and a former accountant--so I was not particularly skilled as a writer, and Dave can't help but edit a document. If a document is placed in front of Dave, his natural instinct is to edit it. And so he would take any note I wrote him, and he would edit it, edit over it in blue pen, and he would send it back to me how I should have written it. And this went on for years... and over time as I would write a document, whether it was to Dave or somebody else, I would say, "How would Dave edit it?" Then I would go back and edit it. And eventually, that just became how I wrote. So when I joined the University of Miami, for example, I joined the University as the CFO and, and other business things, but people consider [me] to be a very 
good writer and they say, "Well, you're a great writer because you worked in journalism for 30 years." And I said, "I mean-I was a business guy. Not a journalist. And the reason why I'm a pretty good writer is because of Dave Lawrence. I was edited by the best, and he edited me for years and taught me how to write." (Joe Natoli, personal communication, August 6, 2015)

\section{Servant-Leader Tenet 10: Building Community}

On October 29, 2013, I attended an institute at the University of Florida in Gainesville that focused on early childhood education and educational leaders. The opening session identified the key components of a responsive educational leader and the learning framework that defines an authentic responsive leader. The keynote speaker, Dr. Patricia Snyder, who holds the David Lawrence Jr. Chair in early childhood studies at the University of Florida, delivered a powerful interactive message about the actions necessary toward responsive educational leaders in early education. She said that "early childhood is the foundation for student success. Educators need to have focused dialogue regarding developmental appropriate practices and intentional learning goals that result in high-quality learning for all children and every child. Feel free to challenge me." Her remarks of challenging every leader have resonated with me since that day. Snyder made a call to action for each educational leader at the institute. She was holding me accountable for my role as a child advocate. As I reflected on Snyder's call to action, I realized that Lawrence had already passionately responded to her call to action for all children in the earliest stages of development, even though he was not in attendance at this institute. Reflecting on professional development opportunities like this institute 
confirmed my desire to better understand the role of an authentic servant-leader in educational reform.

Each participant in this research provided information which corroborated the leadership traits of Lawrence. Torres shared the following:

I've known David for many years. I met him... first when we established the ... the Early Learning Coalitions. Back then, it was called the School Readiness Coalition. In 1999, Lawrence was a big part of establishing the...the coalitions ... I met him because I was a board member back then. And I've been working with him ever since — a good friend, good mentor, an amazing — an amazing person.

David... I think more than anything else he's a mediator and he likes to bring groups together.... He likes to make people feel good. He likes... to talk and communicate. And he is about building something better than what we have now: whether its community... you know, trying to get different organizations to work together..., he is also very focused on working with high-need communities. You know, poor communities that ... where children don't have the same opportunities. David spends a lot of time doing that. He also loves...to give people advice. Go to Coral Bagels, have breakfast with David and whether it's a college student or a high school student or someone working on their doctorate or, an executive director of an organization that may be struggling, David will sit with them; he's a really good sounding board. He will give you just ... good advice. And he's also really good at connecting people with other people. He does that all the time. I think that at a local level, but also at a state and a national level. 
He's done so much, like with The Children's Movement of Florida, working with the Florida Chamber and with the business community. (Evelio Torres, personal communication, July 28, 2015)

On October 17, 2015, at a charity function at the Biltmore and almost two years after Dr. Snyder's call to action, 2016 United States presidential candidate and former governor Jeb Bush described David Lawrence Jr. as a unique leader. Bush openly shared his sentiments regarding the exemplar model of my case study. I was pleased that his words did not surprise me and that they clearly reiterated the themes that had emerged throughout the research:

So there is nothing personal about Dave's work. He doesn't have any personal ambitions. He has already been successful. It's his passion that motivates him. He is kind of like Switzerland. No one has to think - well, there is a hidden agenda or there is something more than what it looks like. There isn't. There is nothing more than what it looks like. He cares about kids. It's plain and simple.

People talk about what science suggests... all the smart people have already decided, but not all the smart people have decided that you have to actually be outcome based. What separates Dave from other people that have a heart and advocate for children is that Lawrence is willing to be held accountable for the things he does. I admire that a lot. If it doesn't work the way he thinks it should work, he will figure out a way to make it work. He will adjust and adapt. I think that comes from The Herald or professional background where he had to manage some really difficult business enterprise and you have to adjust all the time. In the social service world that is not common. So he has taken his life experiences and 
applied it in a way, a selfless way. He is a servant-leader and we need more of them. I am a big fan of his.

Perez summed up the model servant-leadership qualities of Lawrence by stating: Dave is not the screaming guy from the pulpit. He is not that type of leader. He is quiet, intellectual, and honest leadership. When you finish talking to him, you feel like you are in the presence of a good man-a man that is not going to waste your money and that is not asking for anything that is personal in nature. He comes across as a good human being that you want to help. When you look at his causes, you feel that he is doing things for the greater benefit of the community. That's what draws people to give. It's not his persistence, although he is persistent about what [he] believes. But there is no guilt to it. If you don't give, you are not going to hell. . (Jorge Perez, personal communication, June 24, 2015) In a series of emails and ongoing text messages during August of 2015, Carol Barnett described her relationship with Lawrence and elaborated on her perspective regarding his leadership style and advocacy for children.

Dave Lawrence is a generous, empathetic man devoted to his passion for education and driven by the needs of his community. He dedicates his time and energy, sharing his extensive knowledge in the hope of providing opportunities for a better life for thousands of children. Most recently, his work with The Children's Movement of Florida was developed to facilitate the recognition that children in the State of Florida must become our highest priority. His tremendous accomplishments and enduring commitment to his goals are inspirational. He has 
most deservedly received countless awards for leadership and outstanding achievements related to his contributions and dedication to children's issues.

Dave leads by example. He has created a strategic plan, developed after extensive research, addressing the changes needed to successfully achieve goals for childhood readiness. His plan includes an appeal to the members of our community, asking for their advocacy and support of the issues affecting the development of the children. He personally advocates an educational and informational approach to leadership, hoping that this knowledge will bring Floridians together to demand we address the urgent need to improve the way we care for our children.

It is all about the children having the opportunity to succeed in life. The research Dave has done on behalf of children indicates the urgency in providing programs offering services to preschool children. Early childhood development and readiness are key to this effort. He truly believes the economic future of our state and the stability, safety, and security of our communities will suffer unless we address early childhood issues. He retired in 1999 as publisher of The Miami Herald to work in the area of early childhood development and readiness for this reason.

Dave has a deep understanding of the important stake children hold in the future of this country. In addition to improving the lives of the children for their own welfare, he invites the public to examine the statistics regarding the negative repercussions of ignoring the plight of young children in our society. Ensuring that each child can read at grade level by third grade is an essential part 
of helping children succeed. He believes investing in young children will lead to a better society with a skilled workforce, and he takes it upon himself to speak on behalf of our youngest citizens, knowing they are the future.

Dave's efforts have been built around the firm belief that Florida's children must be viewed as the highest priority when it comes to receiving a full and fair share of the state's resources. The Children's Movement of Florida does not advocate new taxes or an increase in existing taxes. Instead, it requests that specific progress be made in investing in programs that help children thrive and succeed. Strides in early childhood education were made with the 2012 legislative agenda, which added a public education component ensuring that more children are reading at grade level by third grade.

Dave had an original, authentic vision for The Children's Movement, which included identifying what state residents viewed as the most important priorities for early childhood programs, and then he built a consensus to achieve those goals. The movement was based on grassroots needs, grassroots support. In a unique appeal, Dave has personally brought all stakeholders to the table and made a case for them to join the effort to make children's issues a priority in the state of Florida. He has worked tirelessly to present his case and convince political, business, and civic leaders to elevate the priorities given to early childhood issues. All have been affected by his genuine, heartfelt plea to be accountable to the children. To quote Dave, "The idea that no matter who they are, what they look like, where they start, how much their parents earn, they can make it if they try...that where you start should not and will not determine how far you can go." 
Knowledge is obtained through the experiences and stories we share with one another. The s of each participant's experience and perspective collectively creates a clear and emerging definition of authentic servant-leadership and advocacy. 


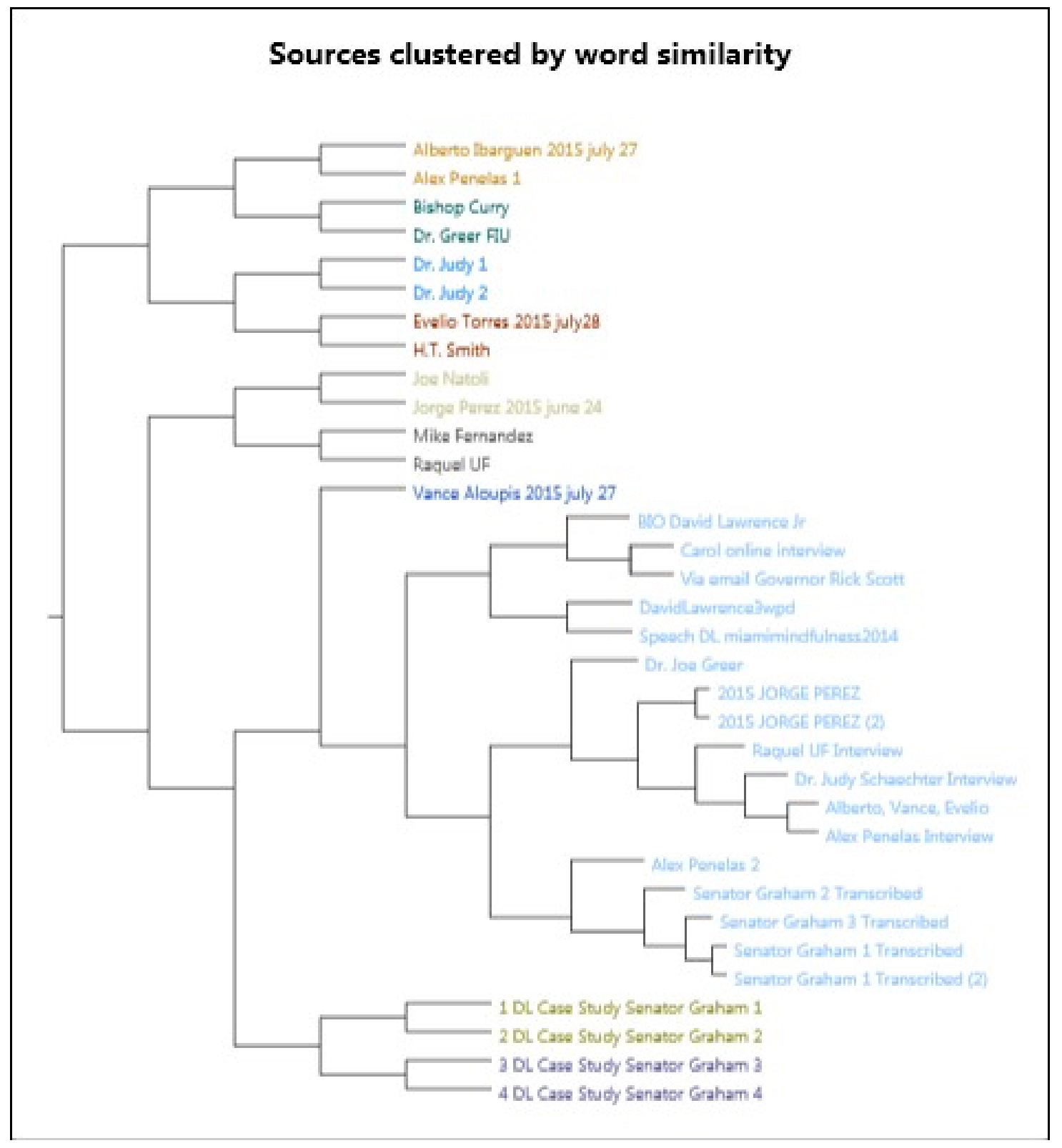

Figure 1. Participants clustered by word similarity 


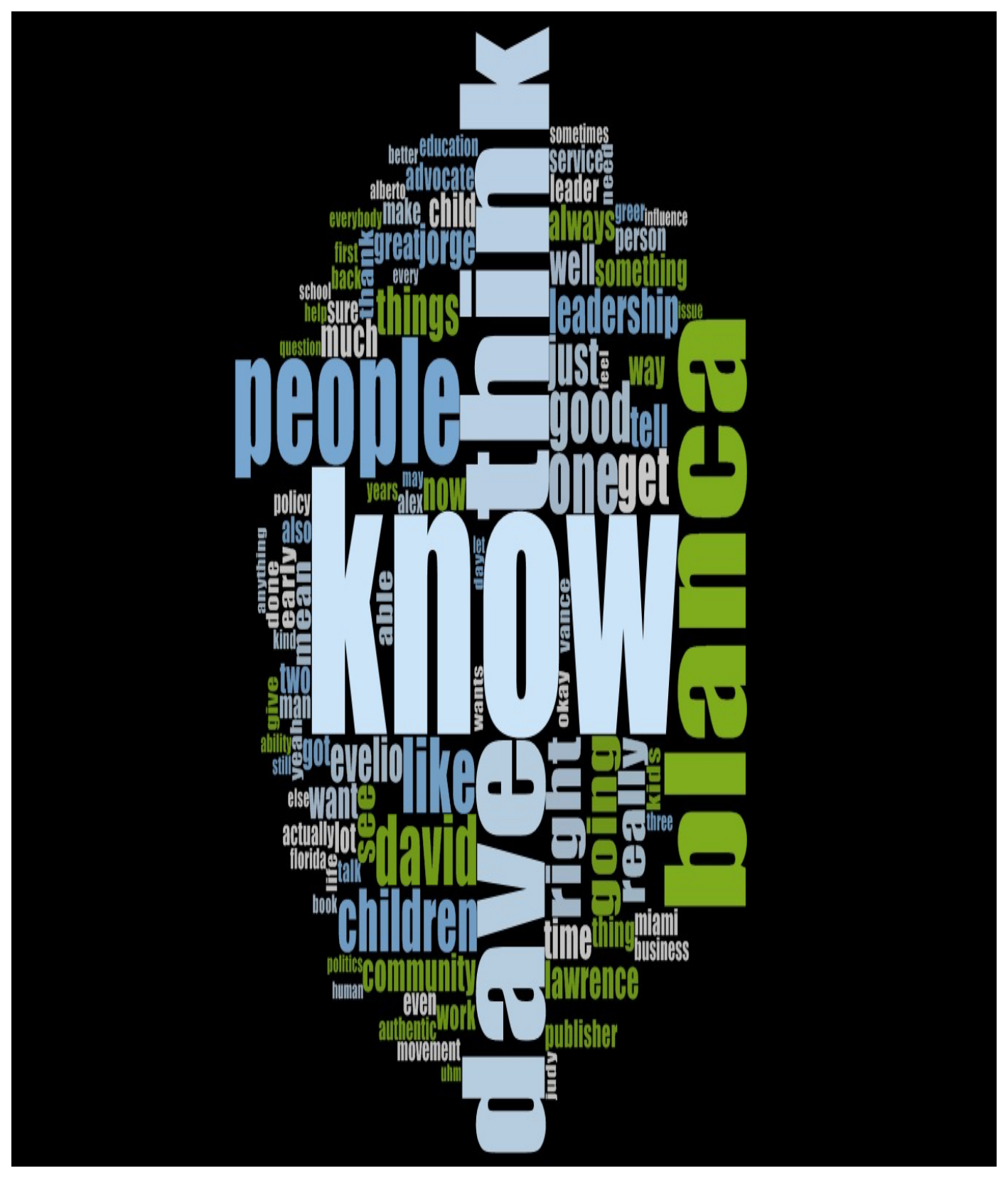

Figure 2. Word Cluster from interviews

\section{Emerging Themes}

David Lawrence Jr. is on a mission-driven life to make the world a better place.

He is driven by his calling and committed to advocate for early childhood initiatives. The findings of this research align Greenleaf's servant-leader tenets with Lawrence's 
leadership style. In addition, the data shows Lawrence exhibits leadership qualities that are listed as emerging themes. These five themes are:

- Passion

Lawrence demonstrates a clear passion for his particular mission and purpose.

- Systematic

Lawrence has a systematic way about his leadership traits and behaviors.

\section{- Optimistic}

Lawrence is optimistic about the good and the potential in others to do greater things.

\section{- Sustainability}

Lawrence knows to help all children he must find a way to sustain the mission, thus he leads by example so others may share in his mission for years to come.

\section{- Urgency}

Lawrence acts in urgency to accomplish his purpose and mission because his life on earth will come to an end, as Lawrence asked Joe Natoli, "What's going to be written on your tombstone?" (Joe Natoli, personal communication, August 6, 2015)

Lawrence's passion, systematic ways, optimism, sustainable thinking and urgency in the matter of children are emerging themes that add to the existing servant-leadership framework coined by Greenleaf.

\section{Passion}

Passion adds life to a servant-leader. Via email on September 14, 2015, Florida Governor Rick Scott explained, "Lawrence's passion for children drives his leadership. 
Growing up, he admired his father's leadership skills and adopted them himself. As a leader, Lawrence always engages stakeholders and does the right thing for children." Natoli described Lawrence's behaviors as passionate:

Dave is an incredibly strong, passionate, dedicated leader, very decisive, very smart, obviously really into the community. So, you know, all those years together at The Miami Herald. I think he would say this: he didn't have a lot of interest in the business part, but he was extremely passionate about the community part. He wrote a column every Sunday- it generated significant response from readers. He immediately responded to every letter that he got. And I mean immediately. I mean, the moment the letters arrived, he had two assistants in front of him, each of whom took dictation, and he would fire off a response saying, "Thanks for the letter. Thanks for your letter." And some comment. He answered his own phone, always.

Natoli explained passion as a particular characteristic specific to Lawrence. He demonstrated passion as a publisher as he valued the community and the information he disseminated through the newspaper. He modeled his passion for the community each time he responded to a reader's letter to the newspaper.

When he traveled—-this was, again, before the Internet—when he traveled, his assistants faxed every piece of correspondence to the hotel. And there was a ton of correspondence. I mean, it would jam up the fax machine. But he has a sense of urgency that required him, and still, he lives this way to this day, I'm sure, to immediately respond to something. I'll go through my emails. If it's something that's going to take more thought than not, I'll skip it and go on to the next one and 
come back to it. I bet you Dave never skips anything. He's too efficient. He would just focus until he had dealt with whatever the issue was. He was very passionate about diversity, is very passionate about diversity. I mean he really believed for The Miami Herald to be successful we needed to really relate to the community, and to be able to do that our staff would have to be representative of the community. And Dave made diversity, really, one of his real pillars. It became a major part of a cultural shift within the Herald. (Joe Natoli, personal communication, August 6, 2015)

As the publisher of the Miami Herald, Lawrence demonstrated passion for the community. Lawrence continues to show passion, specifically for the youngest members of society. His passion is evident through the interviews and stories shared by the participants.

Curry described Lawrence's passion for others:

David has a passion for people, first. Then he has a passion for, this community, and then he has a passion for children, give them a firm foundation. I think he's passionate about the fact that there are a lot of people who have been lost, falling through the cracks, its minority children. I think his compassion, motivates his passion and he's a blessed man. He doesn't mind sharing his blessings. And he's deeply religious. That's his core, and, and, and being a pastor myself, and the whole early childhood, in Matthew 19:14 Christ saying, "Suffer little children, and forbid them not, to come unto me: for of such is the kingdom of heaven." And they asked Him, "Who was the greatest?" and Christ took a little child, and sat 
that child before them and said, "Unless you, "humble yourself like a little child, and be converted, you have no part in the kingdom."

So I think that also motivates David. He sees such great potential in children if we give them a good head start, no pun intended. You know, —his values, his core values are centered on his faith- his passion and compassion for people and children. I think-I think that that's his foundation and that's what motivates him mostly. (Bishop Victor Curry, personal communication, August 5, 2015)

Curry explained how Lawrence's actions demonstrate passion for all children. Lawrence identified the achievement gap and continues to argue that the feasible solution to the problem in society today is building a quality early childhood educational foundation. Lawrence advocates for all children’s early start.

Penelas shared on Lawrence's attitudes and passion:

I met Dave Lawrence in the late '80s... early '90s, as a result of the role that he played with The Miami Herald. I was an elected official so there were different opportunities to exchange ideas... thoughts...comments... with the media, and he was obviously a very prominent member of The Miami Herald. ...

His passion- I've been most impressed with is his commitment to the issue of children. Some people do these things for a year or two and then just let them go. David has stuck to it; he believed in it while he was the publisher; he's believed in it since he left and he just keeps chipping away, chipping away, chipping away, chipping away -- what I've been most impressed with is his staying power -- his commitment and dedication to the issue of children. For someone who can probably retire at this point, you know, he's probably sufficiently comfortable 
from an economic perspective where he doesn't need all of this, but he's remained very committed to it. Now that's very impressive. I'm delighted...I am an interested observer of what's going on. I love it. I love to see people like David Lawrence who are giving their heart and soul back to the community. (Alex Penelas, personal communication, August 8, 2015)

The insight on Lawrence's passion from Penelas’ perspective argues that Lawrence indeed has a passion for people, especially children. Lawrence has a passion for helping the community and is on mission to help all children get a fair start to achieve their dreams.

Perez described Lawrence's leadership with concise words about his servantleadership qualities:

He is passionate and caring. Those are the two words to describe him. He is passionate about children, and he cares deeply about the early childhood cause. He has been able to get to the right people, build coalitions from both the business and political side. For example, he took me and a few other people to Tallahassee when he made his presentation to make sure that the politicians know he has important people behind him. Although he is not a political animal, he is able to swim the political waters in a very efficient way. . (Jorge Perez, personal communication, June 24, 2015)

Aloupis described Lawrence as a leader with passion beyond any mediocre leader:

If Lawrence wanted to shut down his career in journalism in 1999 and say, "I am going to retire and relax for the rest of my life," he could have absolutely done 
that. His legacy in journalism would still be one as that was hugely great. But what he did was that he stepped away from a place where he was very comfortable, where he had achieved huge success and he stepped into another realm. He knew very little but was passionate, and he took that passion and became a leading figure by building an entirely new career. (Vance Aloupis, personal communication, July 27, 2015)

Torres shared his perspective on Lawrence's passion:

I think it's his passion. I think he's trying to set an example. Dave has really good kids also and he's trying to set, set an example for his kids -- the example of good work ethics. (Evelio Torres, personal communication, July 28, 2015)

\section{Systematic}

Graham explained additional insight about Lawrence:

Dave is a very eclectic civic person and has lots of interests. He has been able to discipline himself to stay focused in terms of his public activities with his issues of children. He has used the skills that he developed as a journalist to effectively reach out to others. (Bob Graham, personal communication, July 9, 2015)

Natoli also addressed Lawrence's order of completing tasks as a publisher as well as his leadership behaviors. Lawrence's leadership traits include systematic ways to accomplish the mission at hand. Natoli explained that Lawrence's own behaviors and attitudes were consistent with his expectations of others. People knew what to expect from Lawrence. (Joe Natoli, personal communication, August 6, 2015). Greer also shared similar anecdotes about Lawrence's patterns of behavior that would align with a systematic 
plan of action for completing his life goals. Perez also mentioned that Lawrence has a method to his madness.

Scott said of Lawrence:

Laser focus, attention to detail, and passion for children make him an influential leader when it comes to providing the tools they need to succeed. In 2002, he was a key advocate in passing a statewide constitutional amendment to provide highquality pre-K availability for all 4 year olds. Along with Lawrence, I appreciate the importance of these years and I want to be sure Florida's children have the best early learning opportunities possible.

\section{Optimism}

Schaechter explained the positive influence on others and Lawrence's attitudes regarding people in general.

Dave really sees the goodness in everyone. ... and if he's not imagining what they can do to help make our community, our society, our state, our region better, our future better...he sometimes_-somehow [is] able to help them imagine what they can do.... and, and they can see his core is so authentic that he, he motivates people to do the same.

Dave is working for greater good. And that greater good is outside himself. It really is for all of us. I suppose sometimes when people are thinking about legacy_legacy is about future. It is beyond oneself. And even there it's sometimes about your name and what people remember you for, etc. I suppose that there may be a little of that in many people. I don't get that sense with Dave. I think he has always, in the time I've known him, which is his post-newspaper 
years, it's been about the, about the future of children, about our community, about education and health, which is also so important to me, about equity. This isn't about what we remember Dave for, this is about who we are.

And you, if you've listened to him [talk] about who we are in Florida, or who we are in America, or who we are in society, or who we are in essence, what humanity is about, we know Dave. Legacy is what it's about for us as human beings and he is really about connecting people so that we are all about that movement. And here I am not speaking about the Children's Movement of Florida; it's so much bigger. That's a vehicle for us to do the right thing. There's a deep belief that... it's almost the opposite of when, when one thinks about the atrocities that are committed by human beings: The Holocaust, Rwanda, etc., and we know that that is a part of human nature. And every human being has that capability in oneself. Lawrence knows how much good and energy and possibility is in every single human being. Some of us see that in action in him. And he can unlock that in us and that potential. Many of us don't live that out -sorry.

My sense is that he, he has that potential to help us as Emily Dickinson says, "We don't know how high we can-."If I am paraphrasing, pardon me, but, how high we can rise until we are asked to- - how high we can reach until we are asked to rise. Well, you know, the John F. Kennedy of "Ask not what your country can do for you but what you can do for your country." Lawrence asks us to do more. He actually doesn't ask us, he tells us_-he makes us believe we can do more and, and, and we want to. . (Judith Schaechter, personal communication, July 30, 2015) 
This description of Lawrence's optimistic attitude is also significantly persuasive. As a servant-leader, Lawrence shares his cause and persuades others to pursue the mission as well. Lawrence's shared greater cause is the mission of high quality early childhood education for all children.

Lawrence's perspective as shared by Torres confirmed Lawrence's optimistic lens as well:

Dave does not recognize his limitations. Dave, you cannot like, call the governor and Senate president. That's what I would say. But Dave does not know his limitations because... I don't know if it's confidence; I think part of it is confidence because he's earned it. That's for certain, but he really doesn't know his limitations. He feels that it doesn't matter if you're the President or you're whomever, if he has to tell you something, he may choose his words a little more carefully, on, on, depending on who he's talking to. He's going to be honest ...you'll appreciate it at the end.

And it may take him several years, as you know, with anybody that does public policy. Dave will meet with anyone that he needs to get his mission accomplished. Dave doesn't always get his way, but he keeps at it. (Evelio Torres, personal communication, July 28, 2015)

\section{Sustainability}

Aloupis explained:

So... again, when you're trying to build something, you're always trying, I mean, you can't, no one can do anything alone. And, I'm sure if you ask Dave, you know, nothing he has done has been because he has the will, the might, the power, 
the resources, the connections to do it. He's brought others to the table, but his ability to push people to a place they didn't even think themselves can go, ... I think it's particularly unique. I see it on a day-to-day basis just within the office. ... and again, and I know, I know it's not something partially we're born with, ... but it's honed over time. And, I keep telling him this: I really want to extract that from you because I think it's incredible how you can push people. I mean... a lot of it is dictated by circumstances of life, where you are. Some things he can say at 73 are things that some people can't say at 30, but ... his love for people and his genuine compassion and his sense of caring are so authentic that it's literally something if we can bottle and sell we'd all be billionaires because it's something people crave so much. Dave pushes people ...he works in a fashion I think that works well for him—I'm not going to wait till tomorrow to do what I can do today_sort of a thing. (Vance Aloupis, personal communication, July 27, 2015)

\section{Urgency}

Aloupis described Lawrence's best practice as one that has become a lost art for many leaders:

People are always sort of trying to prioritize things in their life and push things off until tomorrow. Dave is whatever is in front of him. That's what he's charging 110 miles per hour at it. Dave's leadership and his management...I guess the analogy I used is it's like you're sitting on the edge of a sword always with David Lawrence. And... on one side of the sword, if you fall out, fall off, and you don't meet his expectations, there is an authentic wrath. There is a fear of, "Oh, my gosh, I've 
upset Dave" .... and he'll let you know. He is very direct; it's not mean-spirited, but you know you have not achieved what we have set out to achieve.

On the other side of the sword is... a genuine and authentic compassion for people and an authentic praise that people crave. That if Dave sends you a note saying, "Great job," there is such an authenticity in that note. Ask anyone from The Herald about what they called, "Dave Raves," where if you had a great story, Dave would say you had a great story in the paper today. It meant so much just to hear that what you were doing your job well... if you don't achieve what you're supposed to achieve, you're going to hear from him, too. But if you exceed the expectations, you're going to know it. Both are so authentic and so deep that it constantly keeps people exceeding, not only his expectations but their own expectations. (Vance Aloupis, personal communication, July 27, 2015)

On August 13, 2015, Professor Raquel Diaz from the University of Florida shared her views about Lawrence. Her attitude and experiences with Lawrence were also positive and confirming that he is an exemplary authentic servant-leader for the cause of improving the life of all children. She elaborated on Lawrence's urgency to handle the early childhood cause at hand.

He's Mr. Children's Trust and—I—he's been campaigning for quality of early childhood; that's his passion. I don't know where he started I know it came from The Herald, but somewhere down the line, his passion has become quality and accessing quality for all children. And by all children, he's not just looking at vulnerable children. He wants everybody to have good-quality education. It just ends up being you're focusing on who needs it more at that time. 
I hear him talking; it's always about all the children. He's visiting the centers, he getting — he understands what's going on, and he wants to reach everybody. I know when he visits centers, he doesn't just visit the high-quality ones. He visits the ones that also need help, the vulnerable ones because it's all children...because it's equitable. It's not equal, it's equitable. He wants all—all children to have the same access of excellence.

I'm a fan. When you say "Dave” people understand—the real deal. Down to earth. He is the real deal. He mentions his family a lot; he mentions his first grade teacher in some speeches. He mentions his grandchildren. He is human, even though he seems superhuman, outside of Miami's circle because he's so amazing. He brings it back to humanity. He once invited a group, a group of, of people to his home. I know he's done that more than once. I was just lucky enough to go once, and he opened his house, felt like a home—it was beautiful—but I remember commenting to him and his wife that it felt like a home. Family pictures. It's real. It's the real deal. He's truly, truly leaving a legacy. He, he's passionate about what he does. And he does it 24/7. He doesn't rest. He doesn't rest.

On September 1, 2015, at Mike Fernandez's home, the final research interview for this case study was conducted. The findings are explicit in the words used by Fernandez to describe Lawrence as a leader:

Dave is a very serious person with a mission in life. Dave is an extremely bright man. I think Dave has had many missions in life, but I think the last, , the last decade has been devoted to how to improve the education, the care and the 
educational structure for Miami-Dade County regarding children. And then his reach has gone beyond just [the] Florida-Georgia line. Many states listen to Dave as the ultimate expert on early childhood education and childhood healthcare. Although he is not a doctor, he understands that without proper nutrition, without proper care, a child is less likely to get ahead..

Dave is driven. Inquisitive. Dave has, a sense of humor that many people do not pick up on, but it's a good one. He is very interested in all people. I remember taking a hike with David and my wife and a friend of his, Marty, and , every time we came across another hiker it was a seven-day hike in the mountains of Northern Spain -- first thing he would ask is, "Where are you from?" I learned very quickly that was his lead to a conversation because once you knew where the person was from, there were always dots he can connect on a subject to potentially be of interest to him. And there was once one time that we stopped, and my wife [had] graduated from the University of Michigan. So she was wearing —it was pouring rain—she was wearing this University of Michigan poncho, and we passed a couple, and the couple said, "Hey, what's your association with the University of Michigan?" And they, they happened to have graduated from the University of Michigan, too. He says, "Where are you from?" and they said, "Colombia." He says, "What part?" "Bogota." And, that led to a series of conversations. Two hours later, we were talking and it turned out that Dave and this individual had happened to be on board years ago, and they remembered each other's work. This man today runs the largest healthcare system for the country of Colombia. He's a doctor, and his wife teaches mindfulness, so 
my wife, of course, is into mindfulness because of Dave. So those two connected, Dave connected, and I was left with Marty.

I think Dave is the kind of guy that leads by example. I can tell you that when we were hiking although he's the oldest -- he was the one always up front. He was walking faster than any of us, and he's at least 10 years younger—older than I am, and I had a hard time sometimes catching up to him. I was somewhat concerned at times about his health, so I tried to tell him to slow down, and the second day he would not slow down. So again it was pouring—-just about most of the time it poured—and I said, "It's interesting because did you see the camel yesterday?" and Marty was already in, in [on] the joke, so he said, "That was a beautiful camel." And Dave stops, "What camel are you talking about?" "Well, it's really not the camel; it's the baby. It was a beautiful baby; it was still like—it was reddish color." "What are you guys talking about?" "There was a camel yesterday; it was the farthest one we passed." He goes, "I don't know! What camel are you talking about?" I said, "My point is, Dave, you're walking so fast, you're missing the experience." He leads by example. I don't think he's a guy that puts up with nonsense. Either you deliver or you'll find your way out the door pretty quickly. He's very demanding on those around him and ultimately makes them better.

Fernandez stressed how Lawrence has urgency about his mission for children. "Any time spent with Dave highlights the priority to help all children now."

\section{Summary}

The data collected and analyzed in this study is summarized in Table 2. This data contributed new knowledge to the field of leadership and child advocacy in educational 
politics and policy. The study was the first of a kind examining an exemplar servantleader influencing education. The findings benefit educational leaders and academia by providing new characteristics and possibilities of Greenleaf's theory of servant-leadership that may influence educational policies and politics. 
Table 2.

Servant-Leadership Framework and themes emerging

\begin{tabular}{|c|c|c|}
\hline $\begin{array}{l}\text { Servant-Leader } \\
\text { Framework }\end{array}$ & $\begin{array}{l}\text { Evidence of participants’ perspective regarding } \\
\text { David Lawrence Jr. servant-leadership }\end{array}$ & $\begin{array}{l}\text { Emerging } \\
\text { Themes }\end{array}$ \\
\hline 1. Listening & $\begin{array}{l}\text { Meets others in a "small-town setting" where } \\
\text { environment is familiar and lends itself for good } \\
\text { conversation }\end{array}$ & \\
\hline 2. Empathy & Compassion; leads by core values & \\
\hline 3. Healing & $\begin{array}{l}\text { Positive; spiritual; transcends beliefs through } \\
\text { actions }\end{array}$ & \\
\hline 4. Awareness & $\begin{array}{l}\text { Morality/ethics; fair; } \\
\text { integrity; honest; genuine; creative; open to } \\
\text { constructive criticism; transparent; trustworthy }\end{array}$ & \\
\hline 5. Persuasiveness & $\begin{array}{l}\text { Influence educational policy; bipartisan; } \\
\text { motivates \& inspires others; intense; driven }\end{array}$ & \\
\hline 6. Conceptualization & $\begin{array}{l}\text { Credible; mindful; self-disciplined; leads by } \\
\text { example }\end{array}$ & \\
\hline 7. Foresight & $\begin{array}{l}\text { Intuitive about others motives; an avid reader; } \\
\text { sense of humor; inquisitive }\end{array}$ & \\
\hline 8. Stewardship & $\begin{array}{l}\text { Community service; hard working leader; high } \\
\text { standards; role model; is not idle; do-gooder }\end{array}$ & \\
\hline $\begin{array}{l}\text { 9. Commitment to the } \\
\text { growth of others }\end{array}$ & $\begin{array}{l}\text { Advocacy; loves people; satisfied by helping } \\
\text { others; mentor; invests in others }\end{array}$ & \\
\hline \multirow[t]{6}{*}{ 10. Building community } & $\begin{array}{l}\text { Student achievement; unites people from all } \\
\text { walks of life; builds consensus; building a legacy }\end{array}$ & \\
\hline & & 11. Passion \\
\hline & & 12. Systemic \\
\hline & & 13. Optimistic \\
\hline & & 14. Sustainable \\
\hline & & 15. Urgency \\
\hline
\end{tabular}


This research presented a case study of a real person who embodies servant-leader characteristics and who has successfully advocated for positive outcomes in early childhood education in Florida. Following the collection of the data, David Lawrence Jr., shared his critical reflection on his own leadership style. He is a man of strong convictions with a strong set of moral values that are basic and straightforward. He remembers so much his parents taught him, beginning with integrity, fairness, and making a difference. Lawrence considers his views idealistic. He is a lifelong learner with a passion for understanding the lessons of history. Lawrence has a deep curiosity about, and a fascination with, people. He clearly understands that each person is capable of great good, yet all individuals are also flawed by nature. Lawrence describes himself an optimist with purposeful energy, and willing to work as hard as necessary. Lawrence explained “I am always insecure as to what I haven’t done and still need to do. That insecurity is blended with the chutzpah to proceed" (Lawrence, personal communication, February 1, 2016). 


\section{CHAPTER V}

\section{DISCUSSION}

David Lawrence Jr. is a contemporary model of authentic servant-leadership. According to Whitney et al. (2010), holistic sustainable approaches are essential for successful leadership goals. Lawrence's leadership style and advocacy is an example of a sustainable approach to highly effective leadership that may be a key component to solving the dire current situation in public education and policymaking.

Educational leaders recognize that all aspects of development are fundamentally interconnected, yet the obvious problem of addressing the educational leaders has been ignored in the pursuit unsettling statistics as current failures of the public educational system. Today's schools have both academic and social concerns that need resolution. Closing the academic gap of achievement has yet to be resolved. In addition, high risks social behaviors among children today add additional failures to schools.

Lawrence advocates and leads a children's movement to focus on what is equitable for all children, with early childhood education as a starting point for true educational transformation. A topic that requires further discussion is the paradigm shift that includes leaders who choose to practice a leadership style of serving the needs of all children rather than pursuing special interest agendas. A call to action to honestly discuss leadership issues in public education needs to be a priority for educational leaders to influence positive student outcomes. This study contributed to the existing research that highlights child advocacy, leadership style, early childhood education, politics, and policies while filling a gap in the literature by showing the influence one man's servantleadership has had on educational politics and policy. 
This research addressed the values of David Lawrence Jr. as an example of a model servant-leader and his relationships within the political arena as a primary element to influence politics and policymaking for the improvement of early childhood educational reform (Novak, 2012). This case study also identified differences in leadership styles and the influence these differences make in society through educational reform specific to early childhood. The findings of this case study were based on qualitative methodology and the data reported ongoing emerging themes of servantleadership modeled by Lawrence. The case study provided a unique perspective into how educational politics and policy are influenced by authentic servant-leadership.

\section{Findings Related to Literature}

The theoretical framework used for this study was Robert Greenleaf's the Servant as Leader. Greenleaf's (1970) 10 characteristic servant-leader framework could be revised to include five additional traits that David Lawrence Jr. exhibited as a servantleader. The additional traits emerged from the interviews and data collected. The five additional characteristics are relevant to an educational leader and builds upon the servant-leadership framework to effectively participate in solving the problems in education. The additional traits that were identified were relevant in fully describing Lawrence's leadership when set out to achieve the vision and mission of The Children's Movement. These five additional characteristics include: (a) a passion for the greater good, (b) the ability to create a plan of action and be systematic to achieve the goal without being blindsided by minor details that can derail a mission, (c) the need to share an optimistic approach with others about the potential within every possibility, (d) collaboration with others to establish a sustainable movement of like-minded passionate 
individuals pursuing a greater good for all, and (e) the urgency that drives the mission and vision to provide quality early childhood intervention programs to all children.

\section{Analysis of the Results of the Study}

After interviewing each study participant, the researcher concluded that Lawrence was indeed a servant-leader. The responses of the16 case-study participants regarding the character traits and behaviors of Lawrence were consistent with a servant-leader. He was described by all participants as an exemplar leader with selfless qualities. He was described as a servant-leader without the participants' always using the servant-leader classification. The qualities of a servant-leader were described repeatedly by the participants in relation to the traits of Lawrence. Lawrence's leadership style and advocacy were repeatedly described as compassionate toward others, especially young children. Although the participants may not all know each other, the answers they gave were consistent as if they had been shared among the participants of the study prior to the interviews. Each interview was confidential, and yet each interviewee corroborated with the information provided by the other participants.

Service was the overwhelming characteristic all participants shared about Lawrence. Each participant repeatedly described Lawrence as a community service leader with selfless motives. Each participant was clear on the motive that inspires Lawrence's work ethics and leadership style. Lawrence's core values and belief system motivates him. Perez described Lawrence as "a good man that is not asking for anything personal in nature." (Jorge Perez, personal communication, June 24, 2015). All the participants indicated that Lawrence’s leadership traits make him a more effective leader that contributes to the success of others. 
The participants' perceived Lawrence’s leadership as being consistently aligned with Greenleaf's (1970) servant-leader framework. The participants each reported Lawrence's behaviors and actions to be consistent with at least six of the 10 traits of a servant-leader. The behaviors were reported either using the same words that define servant-leadership or concepts that infer the traits. Each interviewee clearly identified Lawrence as a game-changer in education. Based on the findings, humility allows him to position himself in in ways offer him the greatest influence to make an impact on the mission he pursues.

The servant-leadership concepts reflected by Lawrence's behavior as described by each participant were consistent with the servant-leadership framework. Lawrence's ability to listen to others was evident in the interviews. He displays compassion toward others and empathy to the situation of those he may not know personally. Lawrence's mission to pursue greater good for the cause of early childhood and to build a better community is clear. Lawrence conceptualized a dream for all children. His mission is to make his dream a reality through influencing public educational policies as well as by changing the perception of other adults regarding the youngest members of society.

\section{Implications}

The servant-leader style of leadership is not the contemporary leadership practice of prominent United States organizations. Rather, transformational leadership style is more prevalent among educational leaders (Bolman \& Deal, 2002). Yet, David Lawrence Jr., throughout his speeches, addresses the audience with rhetorical questions to provoke thinking and cause the audience members to reflect on their personal ethics in relationship to all children. Are the leaders seeking to serve the needs of the youngest 
members of society? Lawrence's passion and urgency in serving the needs of the community, starting with the youngest members of society, is an ancient practice that can revolutionize public education. The concept of leadership through acts of service was established thousands of years ago. The primary implication resulting from this study is the challenge presented to educational leaders to acknowledge both the responsibility of an educational leader and the special-interest motives that have taken a priority over the best interests of all children. For a leader to transform, the first step is to recognize the patterns and behaviors of his or her professional practice. Ongoing reflection of the motives that drive the leader may be a first step to identify whether the leadership practice and goal is for service to all children as opposed to selfish acquisition of power and material gain.

\section{Implications for Theory}

This research supported Greenleaf's theory as the 10 characteristics associated with a servant-leader were evident in this study. Furthermore, five additional tenets were identified that extend Greenleaf's theoretical work. The implication of adding five tenets to the existing framework supports theory building. The five tenets identified enrich what we already know about the servant-leadership model by providing an additional perspective to examine and understand the influence of a servant-leader in educational settings. These five tenets are passion, a plan of action, optimism, sustainable strategies, and urgency. When linked to the cause of a servant-leader they provide valuable new factors to the existing framework identified by Greenleaf (1970). 


\section{Implications for Future Research}

According to the National Assessment of Educational Progress (NAEP, 2012), closing the achievement gap is a goal of both national and state educational policies. Results from long-term trend assessments show some progress, but continue to illustrate the need to close the gap. Trends in student performance based on demographic characteristics and educational experiences are reported by NAEP, but cannot be used to establish causal relationships. Only statistically significant differences regarding assessment scores seem to be discussed as being either higher or lower, rather than focusing on promising leadership styles like servant-leadership that might positively contribute to better student outcomes, academic or otherwise. The notion of how a specific type of leadership might be linked to achievement or educational practices and policies is not addressed specifically by NAEP. Further research on the characteristics of servant-leadership, such as the five new ones identified in this research (passion, plan of action, urgency, optimism, sustainable strategies), could be examined as predictors of student achievement. Moreover, additional qualitative research investigating how and why servant-leadership is associated with student achievement seems warranted. In addition it might be interesting to extend this research to examining servant-leadership with the five new characteristics in settings outside education. For example, the validity of these findings could be further developed through examining servant leadership in business settings. The overall implications include recommendations for additional research regarding educational best practices, policy and educational politics. 


\section{Implications for Practice and Conclusions}

Based on the findings, it might be useful to design professional development activities that might improve principal servant-leadership traits. In particular, active listening, plan of action, and urgency would be the best traits to begin the journey of understanding and developing the servant-leader. Follow-up professional development might include focusing on fostering passion, optimism, and building a sustainable organization or community.

On the other hand, to improve my own practice as an educational leader, I must continue to reflect on my leadership traits and behaviors. All traits of a servant-leader are equally important, but urgency in making the world a better place is a priority. Public education too often has become a platform for narcissistic leaders pursuing selfish agendas. Although it would seem that children would be the priority when creating educational policies that is not always the case. The ongoing reality that public education may be failing our children continues to be ignored and avoids addressing the obvious problem—self-centered leadership. The arguably selfish gains of educational giants are driving political agendas that are compromising the future of an educated citizenry and a democratic society. The rhetoric must stop and bold and courageous educational leaders must encourage a paradigm shift to change the culture and build the next generation. In the words of Frederick Douglass, "It's easier to build strong children than repair broken men." This is not a new thought, yet the reality has been ignored for too long. 


\section{REFERENCES}

Adler, M. (1982). The Paideia proposal: An educational manifesto. New York, NY: Macmillan.

Antonaros, M. (2010). Gender differences in leadership style: A study of leader effectiveness in higher education. (Ph.D., University of Michigan), 253. (3406225)

Baxter, P., \& Jack, S. (2008). Qualitative case study methodology: Study design and implementation. The Qualitative Report, 13(4 December), 544-559.

Berlowitz, M. J., \& Long, N. A. (2011). The proliferation of JROTC: Educational reform or militarization. In K. Saltman \& D. Gabbard (Eds.), Education as enforcement (pp. 26-36). New York, NY: Routledge.

Bishop, W. H. (2013). Defining the authenticity in authentic leadership. The Journal of Values Based Leadership, 6, 1-8.

Bolman, L. G., \& Deal, T. E. (1991). Leadership and management effectiveness: A multiframe, multi-sector analysis. Human Resource Management, 30, 509-534.

Bolman, L. G., \& Deal, T. E. (1992a). Images of leadership: Your board's leadership style depends on how you see your school. The American School Board Journal, 179(4), 36-39.

Bolman, L. G., \& Deal, T. E. (1992b). Leading and managing: Effects of context, culture, and gender. Educational Administration Quarterly, 28, 314-329.

Bolman, L. G., \& Deal, T. E. (1992c). Reframing leadership: The effects of leaders' images of leadership. In K. E. Clark \& M. B. Clark (Eds.), Impact of leadership. Greensboro, NC: Center for Creative Leadership.

Bolman, L. G., \& Deal, T. E. (1997). Reframing organizations: Artistry, choice, and leadership ( $2^{\text {nd }}$ ed.). San Francisco, CA: Jossey-Bass.

Bolman, L. G., \& Deal, T. E. (2002). Leading with soul and spirit: Effective leadership in challenging times boils down to qualities such as focus, passion and integrity. School Administrator, 59(2), 21-26.

Bryant, D. A. (1992). 150 years of kindergarten: How far have we come? Early Childhood Research Quarterly, 7, 147-154.

Chomsky, N. (2011). The function of schools: Subtler and cruder methods of control. In K. Saltman \& D. Gabbard (Eds.), Education as enforcement (pp. 181-192). New York, NY: Routledge. 
Cistone, P. (2011, July 13). Educational Politics. Lecture presented at Doctorate Studies in Florida International University, Miami.

Connelly, F. M., He, M. F., \& Phillion, J. (Eds.). (2008). The Sage handbook of curriculum and instruction. Los Angeles: Sage. Freire, P. (2000). Pedagogy of the oppressed. (30th ed.). New York, NY: Bloomsbury Academic.

Covey, S. (2004). The 8th habit: From effectiveness to greatness. New York, NY: Free Press

Covey, S. (1989). The seven habits of highly effective people. New York, NY: Simon and Schuster.

Creswell, J. (2013). Qualitative inquiry and research design. (3rd ed., pp. 42-67). Lincoln, NE: SAGE Publications.

Darder, A. (2002). Reinventing Paolo Freire: A pedagogy of love. Boulder, CO: Westview Press.

Deal, T \& Peterson, K. (2009). Shaping School Culture Pitfalls, Paradoxes, \& Promises. San Francisco, CA: Jossey-Bass.

Donaldson, G. (2001). Cultivating leadership in schools: Connecting people, purpose, and practice. New York, NY: Teachers College Press

ECRP: Early Childhood Research \& Practice. (n.d.). Retrieved February 2, 2015, from http://www.ecrp.uiuc.edu/

Ebbeck, M., \& Waniganayake, M. (2005). Early childhood professionals leading today and tomorrow. Australia: Elsevier: Reed International Books Australia.

Fernandez, M. B., \& Merzer, M. (2014). Hbled by the journey: Life lessons for my family ... and yours.

Freire, P. (2000). Pedagogy of the oppressed. (30th ed.). New York, NY: Bloomsbury Academic.

Freire, P. (2005). Teachers as cultural workers: Letters to those who dare teach. Boulder, CO: Westview Press.

Geuras, D. \& Charles G. (2011). Practical ethics in public administration (3rd ed.). Vienna, VA: Management Concepts

Greenleaf, R. K., \& Spears, L. C. (1998). The power of servant-leadership: Essays. San Francisco, CA: Berrett-Koehler Publishers. 
Greenleaf, R. K. (1970). The servant as leader. Atlanta, GA: The Greenleaf Center for Servant Leadership.

Hampton, J. (2004). How Florida's voters enacted upk when their legislature wouldn't. Foundation of Child Development Case Study.

https://www.facebook.com/humbledwalkingforthechildren.

http://www.playgroundprofessionals.com. Froebel, Friedrich (1782-1852) - Biography, Froebel's kindergarten philosophy, The Kindergarten Curricul, Diffusion of the Kindergarten.

https://www.youtube.com/watch?v=6ySs2rLcPhU and Humbled Hiatt, E. (2010). Analysis of servant-leadership characteristics: Case study of a for-profit career school president. (Ph.D., Capella University), 117. . (3389875)

Irwin, J. (2012). Paolo Freire's philosophy of education. New York, NY: Continuum International Publishing Group.

Janesick, V. (1998). Stretching exercises for qualitative researchers. Thousand Oaks, CA: Sage Publication.

Johnson, C. (2012). Meeting the ethical challenges of leadership: Casting light or shadow (4th ed.). Los Angeles, CA: Sage.

Kingdon, J. (2011). Agendas, alternatives, and public policies. Boston, MA: Pearson Education.

Kirp, D. (2013). Improbable scholar. New York, NY: Oxford University Press.

Lawrence, D. (2012, September 12). FIU leadership lecture. Florida International University, Miami, Florida.

Lawrence, D. (2014a, October 18). Mindful speech. Mindful conference, University of Miami, Coral Gables, Florida.

Lawrence, D. (2013, November 14). Speech. Florida Council of 100, Palm Beach, Florida.

Lawrence, D. (2014b, May 8). North Carolina smart start speech. Greensboro, North Carolina.

Lawrence, D. (2015, November 10). Speech. Oklahoma City, Oklahoma.

Lightfoot, S. (1988). Balm in Gilead: Journey of a healer. Reading, MA: AddisonWesley Pub. 
Lochner, L., \& Moretti, E. (2004). The Effect of Education on Crime: Evidence from Prison Inmates, Arrests, and Self Reports. The American Economic Review, 94, 155-189. doi:10.1257/000282804322970751

Merzer, M. (2008). The billion-dollar bet on a community. Miami, Florida: The W.K. Kellogg Foundation, The Early Childhood Initiative Foundation, University of Florida's Lastinger Center for Learning, and The Children's Trust.

Marshall, C., \& Gerstl-Pepin, C. (2005). Reframing educational politics for social justice. Boston, MA: Pearson Education, Inc.

McLoyd, V. C. (1998). Socioeconomic disadvantage and child development. American Psychologist, 53, 185-204. doi:10.1037/0003-066X.53.2.185

Mertens, D.M. \& Wilson, A.T. (2012). Program evaluation theory and practice. New York, NY: The Guilford Press.

Miller, R. (1997). What are schools for? Holistic education in American culture. (3rd ed.). Brandon: Holistic Education Press.

Mills, A., Eurepos, G., \& Wiebe, E. (2010). Encyclopedia of case study research (Vol. 1). Thousand Oaks, CA: Sage.

Moore, T. \& Oberklaid, F. (2010). Investing in early childhood education and care: The health and wellbeing case. International encyclopedia of education, 32-37.

No Child Left Behind. (2002). U.S. Department of Education. Retrieved September 6, 2007, from http://www.ed.gov/nclb

No Child Left Behind. (2002). Retrieved from http://www2.ed.gov/policy/elsec/leg/esea02/ index.html

No Child Left Behind. (2002). Retrieved from http://www2.ed.gov/programs/titleiparta/parentinvguid.doc $\cdot$ DOC file

(n.d.). Retrieved from http://education.stateuniversity.com/pages/1999/FroebelFriedrich-1782-1852.html">Friedrich Froebel (1782-1852) - Biography, Froebel's Kindergarten Philosophy, The Kindergarten Curriculum, Diffusion of the Kindergarten

(n.d.). Retrieved from http://childrensmovementflorida.org/about/history/

(n.d.). Retrieved from http://nces.ed.gov/nationsreportcard/subject/publications/main2012/pdf/2013456. pdf

(n.d.). http://nces.ed.gov/ 
Norton, Mark R. (Ed.). (1996). Holy Bible, New Living Translation. Wheaton, IL: Tyndale House,.

Novak, D. (2012). Taking people with you. New York, NY: Penguin Group.

Orr, D. W. (2004). Earth in mind. Washington, DC: First Island Press Paperback.

Pioneers in our field: Friedrich Froebel- founder of the first kindergarten. (2000, August). Scholastic Early Childhood Today.

Plevyak, L. H. (2003). Parent involvement in education: Who decides? The Education Digest, 69(2), 32-38.

Pyrczak, F. (2008). Evaluating research in academic journals (4th ed.). Pyrczak Publishing.

Rubin, H., \& Rubin, I. (2012). Qualitative interviewing: The art of hearing data (3rd ed.). Los Angeles, CA: Sage.

Saffell , D., \& Basehart, H. (2009). State and local government: Politics and public policies. (9th ed.). New York, NY: McGraw-Hill Higher Education.

Saldana, J. (2009). The coding manual for qualitative researchers. Los Angeles, CA: SAGE.

Saldana, J. (2013).The coding manual for qualitative researchers (2nd ed.). Los Angeles, CA: SAGE.

Spears, L. (1996). Reflections on Robert K. Greenleaf and servant-leadership. Leadership \& Organization Development Journal, 17, 33-35.

Stake, R. E. (1995). The art of case study research. Thousand Oaks, CA: Sage Publications.

Torres, C. A. (2014). First Freire. New York, NY: Teachers College Press.

Whitney, D., Trosten-Bloom, A., \& Rader, K. (2010). Appreciative leadership. New York, NY: McGraw Hill.

Yin, R. K. (1981). The case study crisis: Some answers. Administrative Science Quarterly, 26(March 1981), 57-58.

Yin, R. K. (2003). Case study research: Design and methods. Thousand Oaks, CA: Sage Publications. 
VITA

\title{
BLANCA CORREA-CESPEDES
}

\author{
1986-1987 \\ A.A., Education \\ Dual Enrollment/Miami Dade College \\ Miami, FL \\ 1987-1989 \\ B.S., Middle School Education \\ Appalachian State University \\ Boone, NC \\ 1989-1990 \\ Beginning Teacher \\ Allapattah Middle School \\ Miami, FL \\ 1990-1992 \\ M.S., Gifted/English \\ Nova Southeastern University \\ Ft. Lauderdale, FL \\ 1990-1993 \\ Teacher of the Gifted- Language Arts \\ Ruben Dario Middle School-MDCPS \\ Howard McMillan Middle School- MDCPS \\ Miami, FL \\ 1993-1996 \\ English Professor \\ Florida Memorial College \\ Miami, FL \\ 1993-1996 \\ KIDS Instructor \\ Miami Dade College \\ Miami, FL \\ 1993-1998 \\ Lead Teacher of the Gifted \\ Blue Lakes Elementary-MDCPS \\ Miami, FL \\ 1996-1997 \\ Educational Leadership Certification \\ Nova Southeastern University \\ Ft. Lauderdale, FL \\ 1998-1999 \\ Teacher of the Gifted-Language Arts \\ Rockway Middle School-MDCPS \\ Miami, FL
}


1999-2006

2006

2012-2013

2013-2014

2015-2016

2016
Special Education/Gifted Chairperson

Glades Middle School-MDCPS

Miami, FL

Assistant Principal

David Lawrence Jr. K-8 Center- MDCPS

North Miami, FL

Assistant Principal Fellow- Ready Schools/Investing in Innovation University of Florida (i3)

Project Lead Strong- MDCPS Resident Principal

North Miami Senior High School

Jose de Diego Middle School

High Performing Leaders Program

Miami-Dade County Public School's Lead Strong

Florida International University Center for Leadership

Miami, FL

EdD in Administration/Supervision

Florida International University

Miami, FL 